\title{
Triatomídeos do Chile $\left({ }^{*}\right)$
}

\author{
por \\ Arthur Neiva e Herman Lent \\ Instituto Oswaldo Cruz \\ Rio de Janeiro-Brasil
}

(Com quatro estampas coloridas e seis figuras no texto)

Os representantes desta familia no Chile não têm sido estudados com o mesmo interêsse que o grupo em questão despertou no Brasil e na Argentina em conseqüência das pesquisas realizadas a respeito do Schizotrypanum cruzi.

Logo que tais investigações se desenvolvam no Chile, o que ocorrerá, porque já ficou comprovada a presença daquele flagelado em exemplares chilenos de, pelo menos, duas espécies que alí ocorrem, os estudos sôbre o assunto tomarão desenvolvimento e o registro de triatomídeos chilenos assinalará a presença de outras espécies.

Aliás, desde 1931, quando Massa Sassi publicou o primeiro achado do Schizotrypanum cruzi em "vinchucas" de Melipilla, os pesquizadores chilenos, animados pelo estímulo do NoÉ, vêm estudando e pesquisando, a exemplo do que ocorre em outros países da América do Sul, todos os aspectos relacionados com o importante capitulo da nosologia americana, o da tripanosomose americana ou doença de Chagas.

Assim, a partir de 1938, começaram a surgir importantes e interessantes trabalhos de Gasic, Gajardo Tobar, Dussert, Faiguenbaum, Neghme. Soza, Bertin, Chait sĉbræ aspectos médico-sanitários da questão, enquanto

Este trabalho foi enviado em 23 de janeirc de 1941, por solicitação do prof. Carlos E. Porter, para publicação na Revista Chilena de História Natural. Com o falecimento de Porter, ocorrido em 13 de dezembro de 1942, fai o trabalho devolvido sem ter sido publicado.

Fazendo-o publicar agora, devo declarar que nenhuma alteração foi realizada no primitivo original, as modificações ocorridas daquela data até a atual não tendo sido levadas em consideração. (Nota de Herman Lent).

* Recebido para publicação a 15 de junho e dado à publicidade em agosto de 1943 . 
Mazza, Gajardo $\mathcal{E}$ Jörg e nós próprios procurávamos estudar questões relativas aos transmissores que, como acontece em outros países, e como se verifica pela contribuição que agora publicamos, devem ser mais numerosos $e$ possuir hábitos de vida diversos.

Eis o motivo pelo qual, na suposição de sermos úteis aos colegas do Chile que se ocupam dêstes assuntos, apresentamos o presente ensaio sôbre os triatomídeos chilenos, elaborado sob o prisma do interêsse regional e que poderá servir como ponto de partida para desenvolvimentos futuros. Como tal, terá as falhas naturais que serão corrigidas depois com o auxílio e a colaboração dos colegas do país amigo.

Não têm sido numerosos os pesquisadores que se ocuparam dêstes hemipteros hematófagos na República Chilena. Como desejamos reünir os dados que sôbre a matéria existem disseminados através de uma rara bibliografia, transcreveremos, a-fim-de auxiliar prováveis investigadores, as descrições originais acompanhadas de nossos comentários com o intuito de elucidar 0 assunto.

Si bem que já em 1784, conforme assinalam Talice, Costa, Rial $\mathcal{E}$ Osimani em sua extensa monografia publicada em 1940, o padre MArTin DOBRIZHOFFER referia-se aos hábitos de hematofagismo das "vinchucas" $€$ que BurMeister, em 1835, dissesse que êste grupo de hemipteros suga sangue de mamiferos, parece-nos que, com referência ao Chile, coube a PoEPPIG, em 1835, pela primeira vez, acentuar o hematofagismo dêstes insetos em relação ao homem $e$ isto aconteceu quando êste autor viajava pelos países da costa sulamericana do Pacífico, entre os quais o Chile, o que realizou durante os anos de 1827 e 1831. Diz Poepprg:

"Eine Wahrhafte Plage ist die ausserordentlich grosse Wanze, Die Vinchuca, die schon von früheren Reisenden, jedoch nur als Bewohnerin der dürren Pampas von San Luis und der nicht viel fruchtbarern Gegend von Mendoza. erwähnt wurde. Aus der Gattung der Reduvien des Fabricius gleicht sie an Gestalt der grössten unserer Baumwanzen, an üblem Geruch der gewöhnlichen Bettwanze, allein an Blutgierigkeit, List und Giftigkeit lässt sie diese weit hinter sich. In grösster Menge hält sie sich in den Strohdächern der Hütten auf, und verbirgt sich am Tage so sorgfältig in denselben, dass man umsonst nach irgend einer Spur suchen würde. Kaum ist aber das Dunkel eingetreten so Kommt sie aus ihrem Versteck hervor und fliegt geräuschlos umher. Selbst auf einer minder empfindlichen Haut lässt ihr Biss Anschwellungen, die unter mehreren Tagen nicht verschwinden und peinlich schmerzen. Niemand Wagt daher im. hohen Sommer innerhalb der Häuser zu schlafen. Die nächtliche Kühle und ein Lager in Entfernung von zehn Schritten von der Hütte giebt ziemliche Sicherheit gegen das Insect, welches nur im Innern der Wohnungen vorkommt.

Das Klima von Chile scheint weiter nach der Küste zu der Vinchuca nachtheilig, denn schon in Santa Rosa gehïrt sie zu den selteneren Erscheinungen, 
und ist eigentlich nur in den Bauernhütten der Anden, ganz besonders um den Rio Colorado (sic) häufig, wohin sie ohne Zweifel erst in neuern Zeiten durch Reisende, die aus den Pampas Kamen, verfflanzt wurde. An den Fledermäusen soll sie gefährliche Feinde haben, welcher Gattung diese letzteren beizuzählen sind, ist mir bei der Unmöglichkeit ihrer habhaft zu werden unbekannt geblieben Wahrscheinlich sind sie jedoch den Chiropteren nahe verwandt, wo nicht genau dieselben, welche die südlichen Anden bewohnen, und später zu erwähnen sind."

Poucos anos depois, em 1839, Darwin poude reafirmar o que dissera PoEppig, ao falar do modo pelo qual foi atacado pelas "vinchucas", tendo experimentado até com um exemplar de Iquique, no Chile. São da $1 .^{a}$ edição da obra clássica do sábio inglês, as palavras transcritas a seguir :

"We crossed the Luxan, which is a river of considerable size, though its course towards the sea-coast is very imperfectly known. It is even doubtful whether, in passing over the plains, it is evaporated, or whether it forms a tributary of the Sauce or Colorado.

We slept in the village, which is a small place surrounded by gardens, and forms the most southern part, that is cultivated, of the province of Mendoza; it is five leagues south of the capital. At night I experienced an attack (for it deserves no less a name) of the Benchuca (a species of Reduvius) the great black bug of the Pampas. It is most digusting to feel soft wingless insects, about an inch long, crawling over one's body. Before sucking they are quite thin, but afterwards became round and bloated with blood, and in this state they are easily crushed. They are also found in the northern parts of Chile and in Peru. One which I caugt at Iquique was very empty. When placed on the table, and though surrounded by people, if a finger was presented, the bold insect would immediately draw its sucker, make a charge, and if allowed, draw blood. No pain was caused by the wound. It was curious to watch its body during the act of sucking, as it changed in less than ten minutes, from being as flat as a wafer to a globular form. This one feast, for which the benchuca was indebted to one of the officers, kept it fat during four whole months; but, after the first fortnight, the insect was quite ready to have another suck."

Pelo diário verifica-se que DARWIN realizou essas observações em 25 de março de 1835 .

Em 1852, Spinola, ocupando-se do estudo dos hemípteros na grande obra de Claudio Gay, descreve o seu Conorhinus sex-tuberculatus que nada mais é do que a mesma "vinchuca" descrita da Argentina anteriormente por KLUG, em 1834, sob o nome de Conorhinus infestans. Nesta ocasião, Spinola acentúa que das oito espécies do gênero que então conhecia, só a que acabava de descrever existia no Chile; faz saber que êstes hemípteros viviam entre as pedras soltas e se aproximavam à noite das casas, alimentando-se do sangue dos mamiferos e do homem.

Depois, em 1860, coube a Philippi referir-se ao assunto, que observou durante sua viagem ao deserto de Atacama, onde poude assinalar, além da 
mesma comum "vinchuca" descrita por SpINOLA, outras três espécies que considerou novas e que descreveu, baseado sòmente em formas jovens (ninfas), com os nomes de Conorrhinus octotuberculatus, Conorrhinus Paulseni e Conorrhinus gracilipes.

Referindo-se às "vinchucas" em Atacama diz serem abundantes nas casas, onde não existem pulgas e percevejos. Indica os hábitos das "vinchucas", escondendo-se nos telhados de onde saem à noite para se alimentarem; também diz que picam indolormente, só muito raramente, em pessoas muito sensíveis, podendo haver reação com febre e tumefação.

Certa vez contou em sua cama 41 "vinchucas" de vários tamanhos, di zendo deverem pertencer a várias espécies. No meio do deserto de Atacama, poude encontrar, embora raramente, "vinchucas" no seu próprio leito.

Em 1901, ReED retoma o estudo dos hemípteros do Chile e, dizendo ter visto os tipos de Philippi no Museu Nacional, considera as três espécies descritas por êste autor como formas imaturas de T. infestans.

Neiva repete, em 1914, a afirmativa de Reed; em 1920, Porter confirma a sinonimia, tendo visto os exemplares sôbre os quais PhILIPPI baseou sua descrição. Entretanto, a-pesar-de não conhecermos êste material, a descrição de Philippi para Conorrhinus gracilipes não se juxtapõe ao aspecto da ninfa de $T$. infestans como se poderá verificar pela transcrição que fazemos:

"Conorrhinus gracilipes Fr. Philippi.

C. undique granulosus, niger; protheracis dorso in parte antica transversim gibboso, carinisque duabus longitudinalibus irregularibus munita, lateribus flexuosis, angulis anticis dentiformibus, prominentibus, posticis rotundatis; scutello plano, triangulari, impressione semilunari prope apicem notato; antennarum articulo secundo piloso, tertio quartoque...; pedibus elongatis, laevibus, tarsis et extremitate tibiarum ferrugineo-pilosis; abdominis margine miniaceo-maculato, maculis in sutura segmentorum dispositis. Long. $93 / 4$ lin., latit. 4 lin., longit. pedum posteriorum $91 / 3$ lin. Nympha. (Fr. Ph.)."

As manchas, de colorido vermelho, do conexivo e o comprimento das patas posteriores dão idéia de espécie diferente. Entretanto, nada podemos opor à observação pessoal dos autores citados.

Sòmente em 1934 é que surgiu o conhecimento da segunda espécie de triatomídeo do Chile, $T$. spinolai, graças a uma pequena nota publicada por Porter. Nesta época ativaram-se as pesquisas sôbre a tripanosomose ameri cana e em 1939 Usinger descreveu como nova espécie, a Triatoma chilena que, em trabalho posterior, nós próprios consideramos idéntica à espécie de PORTER. 
Em 1940, Mazza, Gajardo $\mathcal{E}$ Jörg, de um lado, Neiva $\mathcal{E}$ Lent de outro, trabalhando em material do Chile, na mesma época, chegaram a conclusões que de todo não se superpõem, os primeiros criando um novo gênero, Mepraia, para a $T$. spinolai Porter como genótipo e identificando exemplares $q$ q ápteros de triatomídeos encontrados por GAJARDO TOBAR á mesma espécie. Os segundos obtendo $\hat{o}$ ô $\mathrm{e} q q$ ápteros de triatomídeos chilenos creando $n$. gen. e $n$. $s p$. sob o nome Triatomaptera porteri, além de referirem, pela primeira vez, outra espécie de triatomídeo presente no Chile, a Eutriatoma rubrovaria.

Meses após, ainda em 1940, NeIva \& LeNT publicam novo trabalho, colocando a $T$. chilena Usinger, na sinonimia de $T$. spinolai Porter, e discutindo o problema novo que se apresentava em relação aos resultados discordantes que apresentavam a publicação de MAZZA, GAJARDo \& JöRg e a nota prévia de NeIVA $\mathcal{E}$ LENT, problema que exige solução definitiva que sòmente pode ser indicada por quem possuir material vivo e puder criá-lo.

Agora, neste trabalho, descrevemos tôdas as espécies que consideramos existentes no Chile, sem levar em consideração a caracterização dos gêneros em que hoje estão incluidas.

De tôdas, damos a sinonímia e bibliografia mais importante sob o ponto de vista entomológico principalmente no que se relaciona ao Chile, e sua redescrição baseada em séries de exemplares, ao lado da descrição original, além de indicações várias sôbre evolução, hábitos e distribuição geográfica.

As figuras coloridas facilitarão o diagnóstico das espécies de tão importantes hematófagos.

\section{TRIATOMA INFESTANS (KLUG, 1834)}

Reduvius intestans Klug in Meyen, 1834, pág. 412.

Reduvius sp.? Poeppig, 1835, págs. 255-256.

Reduvius sp.? Darwin, 1839, pág. 403.

Conorhinus Renggeri H. Schaefrer, 1848, pág. 71, pl. 271, fig. 838.

Conorhinus sex-tuberculatus SpINola in Gay, 1852, pảgs. 218-221.

Conorhinus Renggeri Stal, 1859, págs. 112-113.

Conorrhinus sextuberculatus PHILIPPI, 1860, pág. 156.

Conorthinus Paulseni PHILIPPI, 1860, pág. 156.

Conorthinus gracilipes PhiLıppi, 1860, pág. 156.

Conorrhinus octotuberculatus PhILIPpi, 1860, pág. 156.

Conorrhinus infestans PHILIPPI, 1860, pág. 173. 
Conorhinus gigas BurM., 1861, págs. 167, 320 (nec Fabr.)

Conorhinus rengerri SignoRet, 1863, pág. 580.

Conorhinus renggeri MAYR, 1868, pág. 151.

Conorhinus sextuberculatus Stal, 1868, pág. 124.

Conorhinus Renggeri Stal, 1872, pág 112.

Conorhinus octotuberculatus Stal, 1872, pág. 112.

Conorhinus Paulseni Stal, 1872, pág. 112.

Conorhinus gracilipes STAL, 1872, pág. 112.

Conorhinus Renggeri Walker, 1873, págs. 13, 16.

Conorhinus infestans BERG, 1879, págs. 165-166.

Conorhinus nigrovarius Railliet, 1895, pág. 819.

Conorhinus infestans Leth. E Sev., 1896, pág. 116.

Conorthinus octotuberculatus LETH. E SEV., 1896, pág. 118.

Conorrhinus Paulseni Leth. E Sev., 1896, pág. 118.

Conorrhinus gracilipes Leth. E SEV., 1896, pág. 118.

Conorthinus sp. Champion, 1899, pág. 206.

Conorhinus infestans REed, 1901, págs. 98-99.

Conorhinus nigrovarius BRUMPT, 1910, págs. 557, 565.

Conorhynus infestans Ihering, 1911, pág. 24.

Triatoma infestans NeIVA, 1911, pág. 462.

Triatoma infestans NeIva, 1913, págs. 24-31.

Triatoma infestans Neiva, 1913, págs. 195, 196 e 197.

Triatoma infestans NeIVA, 1913, págs. 366, 367.

Conorhinus infestans BRUMPT, 1913, pág. 632.

Triatoma infestans NeIva, 1914, págs. 7, 8, 10, 11, 13, 14, 16, 34, 35, 45-46, 66.

Triatoma infestans NeIVA, 1914, págs. 334, 335.

Triatoma infestans Nerva, 1914, págs. 36, 38, 39.

Triatoma infestans PORTER, 1920, págs. 16-19, fig. 2.

Triatoma infestans Del Ponte, 1921, págs. 28, 29, 32, 44-45, figs.

Triatoma infestans HusSEY, 1922, págs. 111, 112, 116.

Triatoma infestans LARROusse, 1924, pág. 67.

Triatoma infestans PINTo, 1925, págs. 15, 19, 25, 28, 29, 38, 57-58, 99, 100 , $102,103,105,107$, fig. 1.

Triatoma infestans Pinto, 1926, págs. 27, 28, 29, 30, 32, figs. 1 4.

Triatoma infestans PINTo, 1927, págs. 105, 106, figs. 2, 4.

Triatoma infestans Del Ponte, 1930, págs. 871, 876-877, 914, 919, 935, pl. 47. fig. 1 .

Triatoma infestans PINTo, 1930, págs. 174, 175, 176, 182, 189, 190, 191, 192, 206, 216-217, 224, est. 4, fig. 1; figs. 49-51.

Triatoma infestans PINTO, 1931, págs. 51, 68-70, fig. 19.

Triatoma infestans NeIVA E Lent, 1936, págs. 153, 171.

Triatoma infestans PORTER, 1939, pág. 124.

Triatoma infestans PORTER, 1939, pág. 155.

Triatoma infestans Gajardo, 1939, págs. 134, 135, 136.

Triatoma infestans Gajardo, 1939, pág. 35, 2 figs.

Triatoma infestans LENT, 1939, págs. 593, 595. 


\title{
Descrição original
}

\author{
(transcrita e traduzida por DeL PONTE, 1930)
}

"Negro, tórax desigual, bicarenado. Hemiélitros oscuros, con la mancha de la base, dos estrias pálidas en el ápice, margen del abdomen manchado de pálido, parecida a Reduvius gigas."

\section{Redescrição}

\section{(Vide estampa 1)}

Comprimento - o $25 \mathrm{~mm}$; \& $26,5 \mathrm{~mm}$.

Largura - (ao nivel do pronoto) \& $5,5 \mathrm{~mm}$; \& $6 \mathrm{~mm}$; (ao nivel do abdômen) ô $8 \mathrm{~mm}$; q $9,5 \mathrm{~mm}$.

Corpo de colorido geral negro com manchas amareladas no conexivo, nos trocânteres e base dos fêmures, e fraca pubescência escassamente distribuida. Esta espécie não possúe tubérculos muito salientes.

Cabeça de colorido preto uniforme, levemente rugosa, com pontuações esparsas onde se implantam pequeninas cerdas escuras dirigidas para diante; sua forma é cilindrica e seu comprimento excede levemente o do pronoto; o tylus é bem visivel e possúe algumas cerdas alongadas anteriormente, é dilatado na base onde, lateralmente, vêm-se os tubérculos parafrontais; jugae distintas mais compridas que o tylus, ao ápice do qual excedem. Região ante-ocular com quase quatro vezes o comprimento da post-ocular. Olhos salientes lateralmente, cada qual tendo de largura $3 / 4$ da distância inter-ocular. Ocelos afastados dos olhos, para trás, grandes e brilhantes, máis próximos entre si, implantados em saliências divergentes, Tubérculos anteniferos implantados no meio da região anteocular, com duas ou três cerdas erectas mais fortes situadas no ápice e lateralmente. $10^{\circ}$ artículo antenal pardacento, dilatado no ápice, năo atingindo a extremidade apical da cabeça, revestido de cerdas escuras dirigidas para diante; $20^{\circ}$ artículo antenal longo, com o mesmo diâmetro e colorido do $10^{\circ}$, com maior número de cerdas e cerca de quatro vezes o comprimento do $1 .^{\circ} ; 3 .^{\circ}$ artículo antenal mais delgado, pardo-claro, com cerdas finas e outras longas aciculares menos abundantes, quase com o mesmo comprimento do $2 .^{\circ} ; 4 .^{\circ}$ artículo com aspecto idêntico ao do $3 .^{\circ}$ e $2 / 3$ do comprimento dêste.

Rostro reto, forte e curto, achatado dorso-ventralmente, preto, com exceção do $3 .^{\circ}$ artículo e ápice do $2 .^{\circ}$, que se mostram extremamente pilosos e de colorido pardacento; $01 .^{\circ}$ artículo é forte e atinge ao nivel da implantação do $1 .^{\circ}$ artículo antenal, as cerdas que o revestem são curtas e escuras; o $2 .^{\prime \prime}$ artículo tem $1,5 \mathrm{vez}$ o comprimento do $1 .^{\circ}$, atinge o bordo posterior dos olhos, quando em repouso, e está revestido de cerdas curtas além de outras maiores abundantes em seu ápice e nos seus bordos laterais; $3 .^{\circ}$ articulo afilado, com $3 / 4$ do comprimento do $10^{\circ}$ e abundantemente piloso.

Pescoço liso, preto, com mancha amarela de cada lado.

Torax de colorido preto uniforme e brilhante com rugosidades, cristas e saliências pouco aparentes.

Pronoto de forma trapezoidal, com distribuïção irregular e escassa de cerdas pequeninas que se implantam em pontuações. O lóbulo anterior do pronoto tem cerca de $1 / 3$ do comprimento de todo o pronoto, e apresenta duas pequenas saliências, com o ápice 
pardacento, de cada lado da linha mediana; abaixo delas, no borbo posterior deste lóbulo, existem outras elevações menores, escuras, de onde nascem as carenas longitudinais que percorrem $2 / 3$ da estensão do lóbulo posterior; entre estas últimas saliências e os bordos laterais são visiveis outras duas elevações; as regiões glabras habituais são também observadas. No bordo anterior do colarinho, implantadas na face interna, existe uma fileira de cerdas maiores douradas que avançam para o pescoço. Lóbulo posterior rugoso, com o sulco longitudinal mediano bem acentuado. Ângulos anteriores do pronoto salientes, com sua face interna escavada em fosseta glabra e pardacenta. Ângulos posteriores obtusos e elevados.

Escutelo triangular, preto, rugoso, com cristas laterais que convergem para o ápice formando um $\mathrm{V}$ e que delimitam uma escavação mediana; o ápice é pouco acentuado, reto, rugoso, rombudo, dilatado na base.

Proesterno preto, sem detalhes maiores a não ser o sulco proesternal grande. Mesoesterno liso, preto brilhante, glabro em alguns pontos e piloso em outros, mostrando em sua parte mediana uma saliência em forma de V. Metaesterno piloso, preto brilhante, na linha mediana possuindo uma crista longitudinal que nasce do mesoesterno. Pro-, meso- e metapleuras pretas, esparsamente pilosas e rugosas, sem maiores detalhes.

Patas de colorido preto, com exceção dos trocânteres, base dos fêmures e tarsos que são amarelados, revestidos de cerdas escuras que se alongam à proporção que caminham para a extremidade da pata. Fêmures com um par de espinhos na região apical e inferior dos dois primeiros pares de patas, que se transfornam em simples saliência no $3 .^{\circ}$ par. Tíbias com fosseta esponjosa nítida nos dois primeiros pares de patas. Tarsos triarticulados, amarelados, abundantemente pilosos, com duas unhas grandes no ápice do último artículo.

Hemi-elitros não atingindo o ápice do abdômen, pardacentos, o cório levemente mais escuro que a membrana, que é pregueada; no cório existem três manchas amareladas, duas na base e outra no limite da membrana. Nervulação como na figura.

Abdomen preto, com fraco revestimento de cerdas curtas e pretas uniformemente distribuidos em toda a face inferior. Orifícios estigmáticos arredondados, amarelos, situados no meio de cada segmento junto ao conexivo. Conexivo largo, arqueado, preto com mancha amarela quadrangular na qual se projeta, irregularmente, a saliência do colorido preto normal do conexivo; também a intersecção entre os scgmentos é amarelada.

Genitália, em ambos os sexos, de colorido preto.

\section{Distribuï̧ão geográfica}

A distribuïção desta espécie é muito vasta na América do Sul, do equador para baixo: Perú, Bolivia, Paraguai, Uruguai, Argentina. Chile e Brasil onde é referida nos Estados da Baía, Minas Gerais, S. Paulo e Rio Grande do Sul.

Seu nome vulgar no Chile é "vinchuca", vocábulo de origem "quechua", segundo Lenz; em Iquique, Porter (1920) registrou a denominação "chirimacho". 


\section{Hábitos}

Vive no interior dos domicilios, nas frestas das paredes ou nos telhados, onde se alimenta do sangue do homem e dos animais domésticos.

Em algumas regiões tem sido encontrada entre as pedras de muros ou nas fendas de rochedos, o que mostra seus hábitos primitivos.

Neiva, em trabalho publicado em 1913, estudou a biologia do Triatoma infestans podendo comparar os hábitos da espécie em material procedente do Brasil com os de exemplares oriundos da Argentina e do Chile. Nesta ocasião foi efetuada, pela primeira vez, a evolução dêste inseto, a segunda espécie do grupo que a isto era submetida. Comprovou-se, então, que certos fatos que se passam com o Panstrongylus megistus ocorrem, também, com o Triatoma infestans, constituindo condição indispensável para a perpetuação da espécie, o hematofagismo.

E resumo, eis como, à temperatura do Rio de Janeiro, ocorre o ciclo evolutivo do $T$. infestans :

A desova é realizada intervaladamente, contudo pode ocorrer que a espécie o faça em dias sucessivos; em geral cada postura póde variar de um a 20 ovos, os quais, em regra, fazem eclosão. Pode haver postura independente de cópula, porém os ovos são infecundos. Os ovos fazem eclosão geralmente após 20 a 25 dias, tendo sido verificado um mínimo de 16 dias e um máximo de 33, prazo variável com a temperatura ambiente, sabido como é que as temperaturas elevadas apressam o desenvolvimento dos seres vivos.

No laboratório, esta espécie se desenvolve em 220 a 240 dias de ovo a adulto, prazo que pode tornar-se mais dilatado, em natureza, em regiões onde a média de temperatura seja mais baixa.

Em 1939, Pessoa \& Barros criaram, à temperatura fixa de $37.0^{\circ} \mathrm{C}$, a espécie em questão e verificaram que o ciclo evolutivo é abreviado podendo se fazer, em média, em 109 dias da eclosão do ovo ao estado de adulto.

Existe necessidade estrita da alimentação sanguínea para que se processem as ecdises; as larvas sugam durante cinco minutos, as ninfas chegam a sugar 10 minutos e os adultos 20 minutos. Os intervalos entre um e outro repasto podem variar de quatro dias a muitos meses; FAIRMAIRE teve ocasião de apresentar à Sociedade de Entomologia de França um exemplar vivo, desta espécie, que resistira um jejum de sete meses; PORTER, no Chile, constatou a sobrevivência de exemplares de $T$. infestans durante 8,10 e 17 meses sem alimentação. 
As "vinchucas" procuram alimentar-se semanalmente; se o repasto for incompleto, êste prazo se abrevia. Os exemplares que sugam em dias sucessivos fazem refeições curtas.

Alguns autores consideram a picada dêste inseto como extremamente dolorosa, podendo até ocasionar reações intensas, com inchação, rubor $e$ febre; outros pesquisadores negam tal fato. Isto parece indicar ser tal reação um fenômeno puramente individual, relativamente raro, e que se apresenta em alguns casos sòmente, porque é muito divulgado o fato de se observarem as "vinchucas" sugando. muitas vezes em grande número, individuos a dormir.

\section{Infestação}

Em natureza foi encontrada infestada pelo $S$. cruzi pela primeira vez, no Brasil, por Carini \& MaCIEL (1914) e existe nestas mesmas condições na Argentina, no Uruguai e no Chile, segundo dados coligidos e publicados por LENT, em 1939.

\section{EUtriatoma RUBROVARIA (Blanch, in Blanch \& Brullé,} 1843)

Conorhinus rub:o-varius Blanchard in Blanchard E Brullé, 1843, pág. 219, pl. 29, fig. 7.

Conorhinus phịllosoma H. Schaeffer, 1848, págs. 70, 71, pl. 271, fig. 837 (nec Burm.)

Conorhinus rubro-varius STAL, 1859, págs. 113-114.

Conorhinus rubro-niger Stal, 1859, pág. 114.

Conorhinus rubro-varius STAL, 1868, pág. 124.

Conorhinus rubro-niget Stal, 1868, pág. 124.

Conorhinus rubro-varius Stal, 1872, pág. 112.

Conorhinus rubro-niger StaL, 1872, pág. 112.

Conorhinus rubroniger WaLKER, 1873, págs. 13, 16 .

Conorhinus rubrovarius WaLKER, 1873, pág. 16.

Conorhinus rubro-varius BERG, 1879, pág. 166.

Conorhinus rubroniger Leth. E SEv., 1896, pág. 117.

Conorhirus rubrovarius Leth. E Sev., 1896, pág. 117.

Conorhynus rubrovarius IHERING, 1911, pág. 24.

Triatoma rubrovaria NeIva, 1913, págs. 196-197.

Triatoma rubroniger NeIVA, 1914, pág. 12.

Triatoma rubrovaria NeIVA, 1914, págs. 7, 60-61.

Triatoma rubrovaria Del Ponte, 1921, págs. 28, 29, 34, 53-54, fig.

Triatoma rubrovaria HuSSEY, 1922, págs. 111, 112, 119-120.

Triatoma rubrovaria LARRousse, 1924, págs. 62, 63, 65, 66-67, 69, fig. 2.

Triatoma rubrovaria PINTo, 1925, págs. 38, 46-49, 99, 100, 102, 103, 105, 107. figs. 31 e $31-$ A. 
Triatcma rubrovaria Gaminara, 1927, págs. 1.260-1.266.

Triatoma rubrovaria Del PonTe, 1930, págs. 894-896, 919, 935, figs. 12-a-b, pl. 44 , fig. 3.

Triatoma rubrovaria Pinto, 1930, págs. 193, 206, 209-210, 224, fig. 74.

Eutriatoma rubrovaria PINTo, 1931, págs. 52, 93, 98-100, fig. 37.

Eutriatoma rubrovaria NeIva E LeNT, 1936, págs. 177, 181, 183, 187.

Eutriatoma rubrovaria Lent, 1939, págs. 594, 596.

Eutriatoma rubrovaria NeIva E LeNT, 1940, pág. 265.

\title{
Descrição original
}

\begin{abstract}
"761-Conorhine varié de rouge. Conorhinus rubro-varius, Blanch. Pl. XXIX, fig. 7.

Niger; capite elongato, thorace sinuato, strigoso, maculis ad angulos posticcs, tuberculisque anticis duobus rubris; elytris nigris, parte coriacea basi apiceque rubra; abdomine marginibus maculis sex rubris.
\end{abstract}

Long, 22 à 24 mill.

Trouvé à Maldonado."

\section{Redescrição}

(Vide estampa 2)

Comprimento: ᄋ 24 a $25 \mathrm{~mm}$; के $21 \mathrm{~mm}$.

Largura - (ao nivel do pronoto) $\$ 5.5 \mathrm{~mm}$; ô $5 \mathrm{~mm}$; (ao nivel do abdômen) $q 10 \mathrm{a}$ $11 \mathrm{~mm}$; ô $7.5 \mathrm{~mm}$.

Corpo de colorido geral preto com manchas vermelhas no pronoto, cório das asas e conexivo, revestido de fraca pubescência que só se acentúa nas tíbias, tarsos e antenas.

Cabeça preta, cilíndrica, mais longa do que o pronoto, granulosa e rugosa, pontuda e com raras cerdas curtas; tylus bem visivel e saliente, dilatado na base e pregueado; jugae distintas ultrapassando o ápice do tylus. Tubérculos parafrontais nitidos. Entre a base do tylus adiante e os ocelos posteriormente existe uma faixa longitudiral mediana que se diferencia devido a maior rugosidade do tegumento.

Região ante-ocular cerca de três vezes maior que a post-ocular. Olhos salientes, não muito grandes, cada qual medindo de largura $3 / 4$ da distância inter-ocular. Ocelos afastados dos olhos, para trás, grandes e brilhantes, mais próximos entre si, implantados em saliências divergentes. Tubérculos anteniferos implantados no meio da região ante-ocular com duas ou três cerdas mais fortes situadas no ápice e lateralmente. Primeiro artículo antenal pardacento, com raras cerdas escuras dirigidas para diante, dilatado no ápice que não atinge a extremidade anterior da cabeça; segundo articulo antenal longo, levemente mais estreito que o primeiro, revestido de cerdas em toda sua extensão, com cerca de quatro vezes o comprimento do primeiro; terceiro articulo antenal mais delgado e um pouco mais claro, com cerdas finas e curtas e outras longas e aciculares menos abundantes, com $2 / 3$ do comprimento do segundo artículo; quarto artículo com aspecto idêntico ao terceiro, um pouco menor do que êle.

Rostro reto, forte, achatado dorso-ventralmente, preto, porém mais claro no terceiro articulo, revestido de cerdas curtas pouco abundantes, que se tornam mais longas e fre- 
quentes no terceiro articulo. Primeiro articulo forte, não atingindo, quando em repouso, o nivel da implantação do primeiro artículo anienal; segundo artículo com o dôbro do comprimento do primeiro, quase atinge o bordo posterior dos olhos e está revestido de cerdas curtas; terceiro artículo afilado, longo, do mesmo comprimento do primeiro e com cerdas mais longas principalmente na ponta.

Pescoço preto, liso, com mancha vermelho-amarelada de cada lado.

Tórax de colorido preto com manchas vermelhas, rugosidades, cristas e saliências pouco pronunciadas.

Pronoto de forma trapezoidal, com distribuïção irregular e escassa de cerdas pequeninas que se implantam em granulações; seu colorido é preto, porém o ângulo posterior e todo o bordo externo do lóbulo posterior é de colorido vermelho formando mancha que ocupa habitualmente o quarto externo do lóbulo posterior, colorido êste que pode tomar todo o lóbulo posterior ou se dispor de forma variável.

A região do colarinho também pode apresentar tonalidade vermelha, o que ainda pode ser observado nos ângulos anteriores.

O lóbulo anterior tem cerca de $1 / 3$ do comprimento de todo o pronoto, tem uma saliência de cada lado da linha mediana, situadas abaixc do sulco que o separa do colarinho, para fora e para baixo delas nascem as carenas longitudinais que se prolongam até quase o bordo posterior do pronoto e entre estas carenas e o bordo externo do lóbulo, quase no limite com o lóbulo posterior, vê-se outra pequena saliência, de cada lado. O lóbulo an. terior é pouco granuloso e possue, também, zonas glabras. Lóbulo posterior rugoso, com o sulco longitudinal mediano acentuado, todo pregueado em vários sentidos. Ángulos anteriores do pronoto dirigidos para fora e para diante : ângulos posteriores obtusos e elevados.

Escutelo triangular, preto, com tonalidade avermelhada, rugoso, provido de uma escavação mediana delimitada anterinrmente por duas saliências pouco pronunciadas; o ápice é reto, rombudo e pregueado; as cerdas são pràticamente inaparentes.

Pro-esterno preto, liso, com cerdinhas espessas, com sulco pro-esternal margeado de calosidades. Meso e meta-esterno lisos, sem cerdinhas espessas, aquêle possuindo uma saliência transversal em forma de barra. Pleuras rugosas e pregueadas, com cerdinhas praticamente inaparentes e grande mancha vermelha no limite posterior da pleura.

Patas de colorido preto uniforme, revestidas de cerdas curtas abundantes que são maiores e mais numerosas nas tíbias e tarsos. Fêmures com um par de espinhos na região apical e inferior dos dois primeiros pares de patas, que se transforma em simples saliência no terceiro par. Tarsos triarticulados, pilosos, com duas grandes unhas no ápice do terceiro artículo.

Hemi-élitros atingindo o ápice do abdômen. Cório preto com pequeninas cerdas espessas e mancha vermelha, na base e no ápice, que varia de extensão conforme o exemplar; mem. brana pregueada, pardacenta. Nervulação como na figura.

Abdômen preto, com fraco revestimento de cerdas curtas. Orificios estigmáticos arredondados, de colorido amarelo-avermelhado, situados no meio de cada segmento junto ao conexivo, que é largo, levemente arqueado, preto com manchas vermelhas, quadrangulares, largas e grandes em cada segmento, de modo que a observação mostra o conexivo vermelho com estreitas faixas pretas sôbre a linha de intersecção dos segmentos, coloridos preto que se superpõe aos bordos inferiores e superiores de cada segmento; sôbre o bordo externo do conexivo várias séries de cerdas pretas curtas.

Genitália em ambos os sexos, muito pilosa. 


\section{Distribuïção geográfica}

Esta espécie é peculiar ao Uruguai, onde é estensamente disseminada; também não é rara no Estado do Rio Grande do Sul (Brasil) e foi encontrada ainda no Estado da Baía. Na Argentina é referida por Del Ponte (1930) em Entre Rios (Stuart Pennington). Existe, ainda, em Java, de onde provieram exemplares determinados por Larrousse e que Cesar Pinto estudou, confirmando; o exemplar descrito por H. Schaeffer, em 1848, sob o nome de Conorhinus phyllosoma também possuia esta mesma procedência. Em 1940, NeIva \&́ LeNT assinalam a espécie no Chile; tratáva-se de um exemplar \& enviado pelo prof. Flaminio Ruiz P. e capturado a $3.000 \mathrm{mts}$ de altura em Membrillo, provincia de Coquimbo.

Talice, Costa, Rial E Osimani, em 1940, não incluem a espécie como existente no Brasil, acreditando, entretanto,

"ser possivel que exista no Estado do Rio Grande do Sul cujas condições biogeograficas são semelhantes ao do Uruguai".

Sua existência no Estado do Rio Grande do Sul não é sòmente possivel e sim real, pois de várias localidades temos examinado exemplares. Aliás, desde 1913. Neiva a assinalou neste Estado e no ano seguinte referiu-se às variações de colorido freqüentemente encontradas, fato que PINTo estuda em 1925 e 1930 comprovando a abundância da espécie não só em domicílio, como nos currais e demais anexos onde vive, nos muros de pedras, alimentando-se no homem, cão, boi, ovelha e cabra.

Os autores uruguaios, baseados em opinião verbal de MAzzA, não a acreditam presente na Argentina, contrariando o que Del PONTE refere em sua monografia.

\section{Hábitos}

Esta espécie tem hábitos predominantemente silvestres e vive, de preferência, em lugares pedregosos onde se abriga sob as pedras ou entre as frestas formadas por seus amontoados, e, naturalmente, nesses locais alimentam-se do sangue dos animais que aí também se escondem.

\section{Infestação}

Sua infestação natural pelo $S$. cruzi foi referida pela primeira vez no Uruguai, em 1923, por Gaminara. 


\section{Criação}

Como tôdas as espécies do grupo, esta é fácil de criar no laboratório, o que há muitos anos foi feito por Nerva de material recebido de Pelotas. Atualmente e há vários anos criamos esta espécie de uma amostra prove. niente do Uruguai e enviada por Talice.

\section{TRIATOMA SPINOLAI Porter, 1933}

Triatoma spinolai Porter, 1933, págs. 192-193.

Triatoma spinolai NeIVA E Lent, 1936, págs. 178, 184.

Triatoma spinolai PORTER, 1939, pág. 124, lám. 8, 1 foto.

Triatoma spinolai PORTER, 1939, pág. 155.

Triatoma spinolai GajARDo, 1939, págs. 134, 135.

Triatoma spinolai Gajardo, 1939, pág. 35, 2 figs.

Triatoma spinolai NeghMe, 1939, pảg. 36.

Triatoma spinolai UsINGer, 1939, pág. 46.

Triatoma spinolai LENT, 1939, pág. 594.

Triatoma chilena UsINGER, 1939, págs. 45-46.

Mepraia spinolai Mazza, Gajardo E Jörg, 1940, págs. 3-30, figs. 1-27, pro parte.

Triatoma spinolai Nerva E Lent, 1940, págs. 265, 266.

Triatoma spinolai Neiva $E$ Lent, 1940, págs. 343, 344, 345, 346, 348, 350, 351 358, figs. 1,4 e 5 .

Sôbre esta espécie e a que a seguir vem publicada, Triatomaptera porteri, fizemos um estudo detalhado (Memórias do Instituto Osvaldo Cruz, T. 35, f. 2, agôsto de 1940, sob o título, "Estudos sôbre Triatomideos do Chile: Interessante caso de provável polimorfismo"), para expor a situação em que se encontram, conforme nosso ponto de vista, sugerindo orientação a seguir para resolver definitivamente a questão.

Não reproduziremos aquí nossos argumentos para não alongar dema. siadamente o artigo.

\section{Descrição original} $5 \mathrm{~mm}$.

"Largo : $20 \mathrm{~mm}$; ancho mayor del abdomen $6 \mathrm{~mm}$ y del pronoto cerca de

Cuerpo angosto. Cabeza bastante prolongada por delante de los ojos; antenas con pelos muy cortos en el $2 .^{\circ}$ artejo; los artejos $3 .^{\circ}$ y $4 .^{\circ}$ claros y con pelos largos; el pico moreno con el último artejo ciliado. El pronoto finamente granuloso lleva adelante dos pequeñas puntas y el lóbulo anterior dividido en dos por un surco mediano y cada una de estas mitades con tres terminaciones a manera de escamas. Las dos carenas longitudinales borradas antes del bordo posterior $y$ un poco divergentes. 
Los hemélitros sobrepasan la extremidad del abdomen y tienen un tinte avellano claro. Los bordes de! abdomen casi paralelos.

Colcres: Cabeza, antenas, pronoto y escutelo morenos. El abdomen tanta por encima como por debajo negro, salvo el conexivo que es uniformemente rojo (ruber en la cromotaxía de Saccardo).

Hab. - Cerca de Vicuña, Dr. A. Iturriaga, leg."

Esta descrição, que não pode ser datada do ano de 1933, porque a rer vista em que foi publicada é distribuida sempre no ano seguinte àquele ao qual se refere, (1) foi divulgada, como nota prévia, para garantir prioridade e baseada em um exemplar macho, não em perfeito estado, como foi dito, ainda por seu autor, à pág. 122 da Revista Chilena de Historia Natural, año 42 (1938) publicada em 1939.

Não era possivel, portanto, a PORTER referir-se ao dimorfismo sexual, como, em 1940, querem Mazza, Gajardo \& Jörg. Também não podemos concordar quando êstes últimos autores dizem:

"Cuando examinamos um Paratypus proveniente de la coleccion de PorTer, pudimos advertir que a más de incompleta la descripción es errónea, ya que los machos de la especie no poseen conexivo dorsal, no pudiendo por lo tanto éste ser uniformemente rojo, como dice el autor.

El conexivo ventral (sólo el del macho) muy estrecho, es efectivamente uniformemente rojo, pero PORTER no hace alusión a esta diferencia de estruc. tura".

E isto fazemos porque recebemos de PORTER, para ser incorporado à coleção do Instituto Osvaldo Cruz, o exemplar holótipo macho de Triatoma spinolai, o único sôbre o qual, repetimos, o conhecido naturalista chileno baseou sua diagnose. Neste exemplar, que redescrevemos a seguir com todos os pormenores que seu estado atual permite, pudemos observar que a des. crição original de Porter, embora resumida, não é errônea. Existe conexivo dorsal e conexivo ventral neste exemplar, muito estreito aliás, como existe também no parátipo de Triatoma chilena, que examinamos. Em ambas as faces o conexivo, no exemplar holótipo de $T$. spinolai, é uniformemente ver. melho, como Porter descreveu.

Porém, êste colorido uniforme no conexivo ou a presença de manchas escuras sôbre èle, dispostas de modo diverso, deve ser uma variação ampla, da qual pudemos surpreender os pontos extremos, enquanto MAzzA, GAJARDO $\mathcal{E}$ JÖRG estudaram exemplares que apresentam um aspecto interme. diário desta variação. Assim, o holótipo mostra conexivo uniformemente vermelho; o parátipo de $T$. chilena UsINGER tem os seguintes caracteres no

(1) Em carta recente, Porter comunica ter distribuido separados em outubro de 1933. 
conexivo, tanto na face ventral quanto na dorsal: $10^{\circ}$ e $20^{\circ}$ segmentos vermelhos, $3 .^{\circ}, 4 .^{\circ}, 5 .^{\circ}$ e $6 .^{\circ}$ com uma faixa preta transversal e mediana, o res, tante sendo vermelho; o $7 .^{\circ}$ segmento vermelho, porém um pouco escurecido no ponto correspondente às manchas dos segmentos anteriores. Isto é, o primeiro exemplar sem manchas e o segundo com grande número delas. As figs. 6 e 7 do trabalho de Mazza, Gajardo $\mathcal{E}$ Jörg esquematizam o conexivo em dois machos alados, todos os dois com a face ventral do conexivo uniformemente vermelha e a face dorsal, num dos exemplares, vermelha nos seg. mentos $10^{\circ}$ e $2 .^{\circ}$, com mancha escura pouco delimitada no $3 .^{\circ}$ segmento; e manchas nítidas nos $4 .^{\circ}$ e $5 .^{\circ}$ segmentos; os segmentos 6 e 7 são vermelhos: na 2. exemplar o conexivo dorsal é vermelho, sòmente com manchas pouco nítidas nos $3 .^{\circ}, 4 .^{\circ}$ e $5 .^{\circ}$ segmentos.

$E^{\prime}$, incontestàvelmente, uma forma de transição e o maior argumento que possuimos para colocar $T$. chilena Usinger na sinonímia de $T$. spinolai PORTER, já que outros caracteres não existem que permitam separar a espécie do autor norte-americano da que Porter descreveu em 1934.

Damos, a seguir, a redescrição do holótipo de $T$. spinolai, com o qual o parátipo de $T$. chilena concorda, à exceção dos detalhes já citados para o conexivo.

\section{Redescrição}

(Vide figura 1)

Comprimento - Macho $22 \mathrm{~mm}$.

Largura - Macho (ao nivel do pronoto) $5 \mathrm{~mm}$; (ao nivel do abdômen) $6.5 \mathrm{~mm}$.

Inseto regularmente desenvolvido, de colcrido geral pardacento, mais escuro na face inferior do abdômen, porém com o conexivo de colorido uniformemente vermelho. A dis tribuição de pêlos é irregular e escassa : existem regiões glabras, outras pouco pilosas providas de pêlos curtos e outras, como tíbias, tarsos, rostro e face inferior do abdômen com pêlos longos e finos mais numerosos.

A espécie é alongada, relativamente delgada, com pernas finas e compridas, principal. mente as do terceiro par.

Cabeça de colorido castanho, que é mais claro nas faces laterais e inerior, delgada, alongada, com $4 \mathrm{~mm}$ de comprimento, levemente mais comprida do que o pronoto, irregularmente rugosa e tuberosa, com cerdas pequenas e esparsas implantadas em granulações e irregularmente dispostas. Região ante-ocular comprida, com cerca de três vezes o comprimento da região post-ocular, com tylus saliente e jugae em plano inferior e não atingindo o ápice do tylus. Algumas cerdas finas e longas são visiveis na face inferior da cabeça, que é menos rugosa. Tubérculos parafrontais visiveis. Olhos salientes, lateralmente situados, mais aproximados entre si na face inferior, cada qual com a metade da largura da distância interocular. Ocelos salientes, grandes, de colorido avermelhado, mais próximos entre si do que os olhos, afastados dêstes últimos e implantados em saliências no limite posterior da cabeça. 


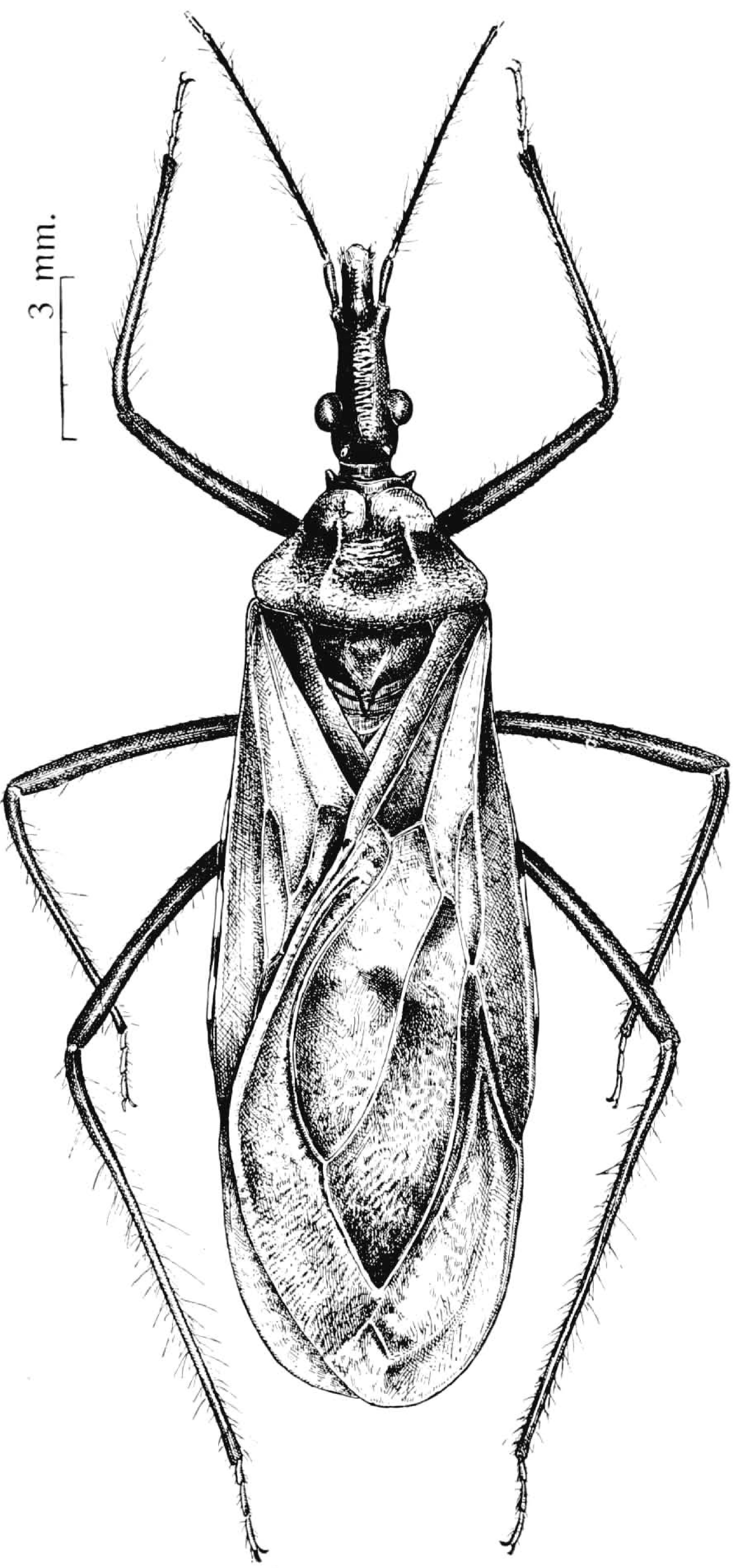

Fig. 1 - Triatomia spinolai Porter, 1933. Exemplar macho, parátipo de Triatoma chilena Usinger, $1939 \mathrm{R}$.
Arlé del.

Tubérculos anteniferos implantados no meio da região ante-ocular, curtos e esparsamente pilosos, com um grupo de cerdas fortes e curtas situadas lateralmente no ápice. Faltam as antenas no exemplar. 
Rostro reto (fig. 4), delgado, longo e achatado dorso-ventralmente, de colorido cas. tanho, revestido de pêlos longos e finos e outros curtos, os $2 .^{\circ}$ e $3 .^{\circ}$ segmentos mais pilosos do que o $1 .^{\circ}$ artículo que é forte e termina ao nivel da implantação do 1." articulo
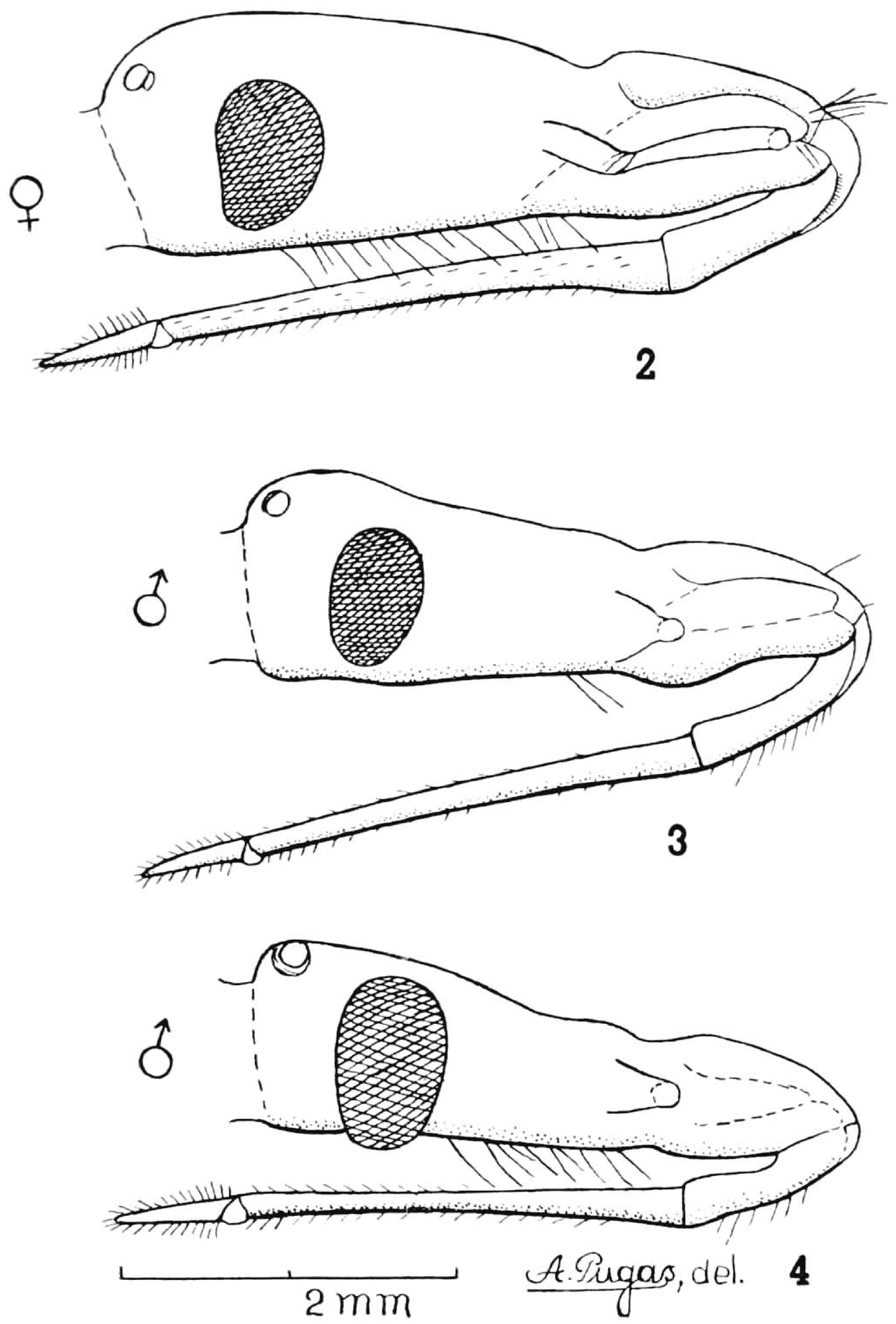

Fig. 2 - Triatomaptera porteri Neiva \& Lent, 1940. Cabeça de perfil, desenhada do alótipo fêmea. Fig. 3 - Triatomaptera porteri Neiva \& Lent, 1940. Cabeça, de perfil, desenhada do holótipo macho. Fig. 4 - Triatoma spinolai Porter, i९33. Cabeça, de perfil, desenhada do holótipo macho.

antenal; $2 .^{\circ}$ articulo muito longo e mais delgado, medindo três vezes o comprimento do 1. ${ }^{\circ}$ e terminando ao nível do pescoço; $3 .^{\circ}$ artículo afilado, mais delgado, com $2 / 3$ do com. primento do $1 .^{\circ}$, repousando no sulco proesternal e atingindo a inserção do $1 .^{\circ}$ par de patas.

Pescoço castanho claro sem manchas. 
Tórax de colorido castanho uniforme, sem manchas, com rarissimos pêlos esparsos, mais abundantes e longos somente nos meso- e metaesterno, e com zonas rugosas, granulosas e glabras.

Pronoto bem constituido, grande, com $3,5 \mathrm{~mm}$ de comprimentc, de forma trapezoidal, dividido no terço anterior por um sulco transversal nitido nos dois lóbulos habituais ao grupo. Lóbulo anterior ocupando o têrço anterior do pronoto, dividido na linha mediana longitudinal por um sulco; existem zonas glabras e simétricas na linha mediana e lateral mente, a superfície do lóbulo é granulosa e apresenta dois tubérculos muito pequenos ao lado do sulco mediano longitudinal; o sulco que limita o colärinho é bem acentuado. Do limite dos dois lóbulos, pràticamente do lóbulo posterior, nascem as duas carenas longitudinais que são paralelas e se prolongam até a metade do lóbulo posterior. Lóbulo posterior também sem manchas, castanho, com a superfície enrugada e granulosa e as partes mediana e laterais escavadas. Ângulos anteriores do pronoto salientes, dirigidos para diante e para fora, de ponta romba. Ângulos posteriores obtusos.

Escutelo castanho, triangular, de tamanho normal, com o ápice enrugado e de ponta romba não levantada. Nota-se uma escavação acentuada mediana e próximo ao ápice; duas outras, uma de cada lado da linha mediana e próximo do bordo anterior do escutelo, menores; e uma depressão em cada bordo lateral.

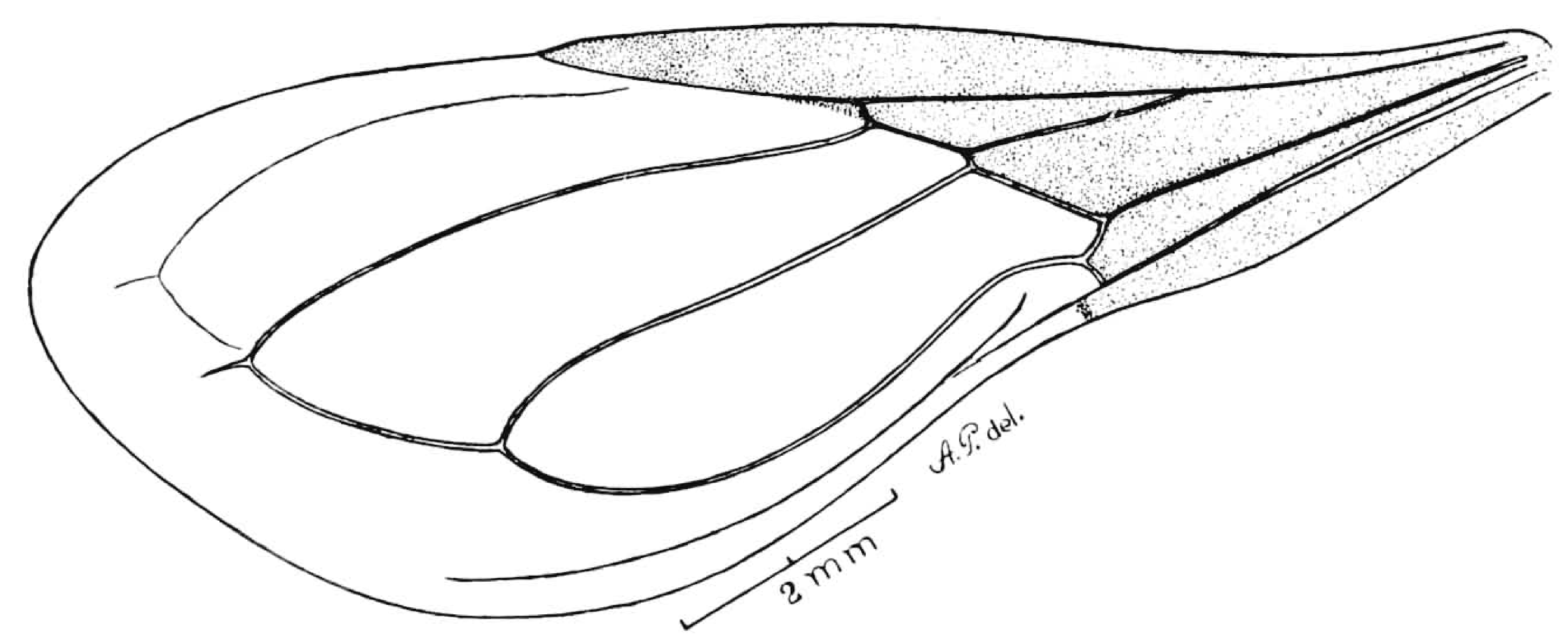

Fig. 5-Triatoma spinolai Porter, 1933. Hemiélitro, desenhado do holótipo

Pro-, meso- e metapleuras granulosas e pregueadas irregularmente. Proesterno ocupado pelo sulco proesternal grande, possuindo, anteriormente, e de cada lado, uma grande protuberância. Mesoesterno mais liso, ainda granuloso, com pêlos finos e longos, com uma crista transversal adiante da implantação do $2 .^{\circ}$ par de patas e onde se inicia uma crista longitudinal que percorre o metaesterno.

Patas delgadas, uniformemente castanhas, longas e revestidas de pêlos finos e longos, mais abundantes nas tibias e nos tarsos. Fêmures sem espinhos. Tibias com a metade do diâmetro dos fêmures e mais longas do que êles nos $2 .^{\circ}$ e $3 .^{\circ}$ pares, com fosseta esponjosa no ápice nos $10^{\circ}$ e $2 .^{\circ}$ pares. Tarsos pardacentos, triarticulados, muito pilosos. Unhas fortes.

Asas bem constituidas, ultrapassando o abdômen, com membrana clara e nervulação como na fig. 5.

Abdômen com pilosidade longa e fina na face inferior e estigmas salientes e amarelados junto ao bordo do conexivo e no meio de cada segmento. 
O conexivo é uniformemente vermelho (2), quer no dorso, quer na face ventral; $\dot{e}$ delgado, muito estreito, porém nitido em ambas as faces. O colorido vermelho avança, também, em faixa sôbre as faces dorsal e ventral do abdômen e, nesta, vai um pouco além do limite dos estigmas. Cada segmento ventral do abdômen possue duas placas estigmáticas glabras em fileira longitudinal.

A genitália é bem constituida e possúe pilosidade abundante, externamente.

\section{TRIATOMAPTERA PORTERI NeIVA E Lent, 1940}

Triatomaptera porteri NeIva E Lent, 1940, págs. 266-267.

Mepraia spinolai Mazza, Gajardo E Jörg, 1940, págs. 3-30, figs. 1-27, pro parte.

Triatomaptera porteri NeIVA E LENT, 1940 , págs. $343,345,346,350,356,357$ 361, figs. 2,3 e 6.

\section{Descrição da espécie}

(Vide estampa 3)

Reproduzimos a descrição de Triatomaptera porteri NeIVA E LENT, 1940, espécie baseada em machos e fêmeas ápteros e cujas fêmeas concordam com os exemplares do mesmo sexo descritos por Mazza, Gajardo E Jörg como Mepraia spinolai (PORTER).

Damos, também, uma figura total do macho sem asas (fig. 6) e desenhos da cabeça do macho e da fêmea de perfil (figs. 2 e 3 ) mostrando nitidamente, em comparação com a fig. 4 , que é de Triatoma spinolai, diferenças quanto à coloração e tamanho dos olhos e ocelos, além de uma estampa colorida.

Comprimento - Machos 18 a $19 \mathrm{~mm}$; fêmeas 20 a $20,5 \mathrm{~mm}$.

Largura - (ao nivel do pronoto) machos e fêmeas $3 \mathrm{~mm}$; (ao nivel do abdômen), machos 5 a $6 \mathrm{~mm}$; fêmeas $7 \mathrm{~mm}$.

Inseto de tamanho médio, uniformemente escuro, preto no abdômen e castanho escuro nas outras partes do corpo, porém com o conexivo irregularmente manchado de vermelho. A distribuição de pêlos é irregular : existem regiōes glabras, outras pouco pilosas e algumas, como tibias, tarsos, fêmures, face inferior do abdômen e rostro, abundantemente providas de pêlos longos e finos.

A espécie é alongada, relativamente delgada, com pernas finas e compridas, principal. mente as do $3 .^{\circ}$ par, e logo se caracteriza pela ausência de asas nos exemplares adultos.

(2) No exemplar parátipo do Triatoma chilena, o conexivo possue as seguintes caracteristicas : $10^{\circ}$ e $2 .^{\circ}$ segmentos vermelho: $3 .^{\circ}, 4 .^{\circ}, 5 .^{\circ}$ e $6 .^{\circ}$ com uma faixa preta transversal e mediana o restante sendo vermelho; o $7 .^{\circ}$ segmento é vermelho porém um pouco escurecido no ponto correspondente às manchas dos segmentos anteriores.

Este exemplar mede $21 \mathrm{~mm}$ de comprimento total e largura de $4,5 \mathrm{~mm}$ (ao nível do pronoto) ou $6 \mathrm{~mm}$ (ao nivel do abdômen). Possuia 4 rótulos : 1) T. Hallinan, Cruz Grande, Coquimbo, Chili Nov. 25-16; 2) Ac. 5.385; 3) Paratype Stenotriatoma chilena Usinger; 4) Stenotriatoma chilena Usinger, Det. by R. L. Usinger. 


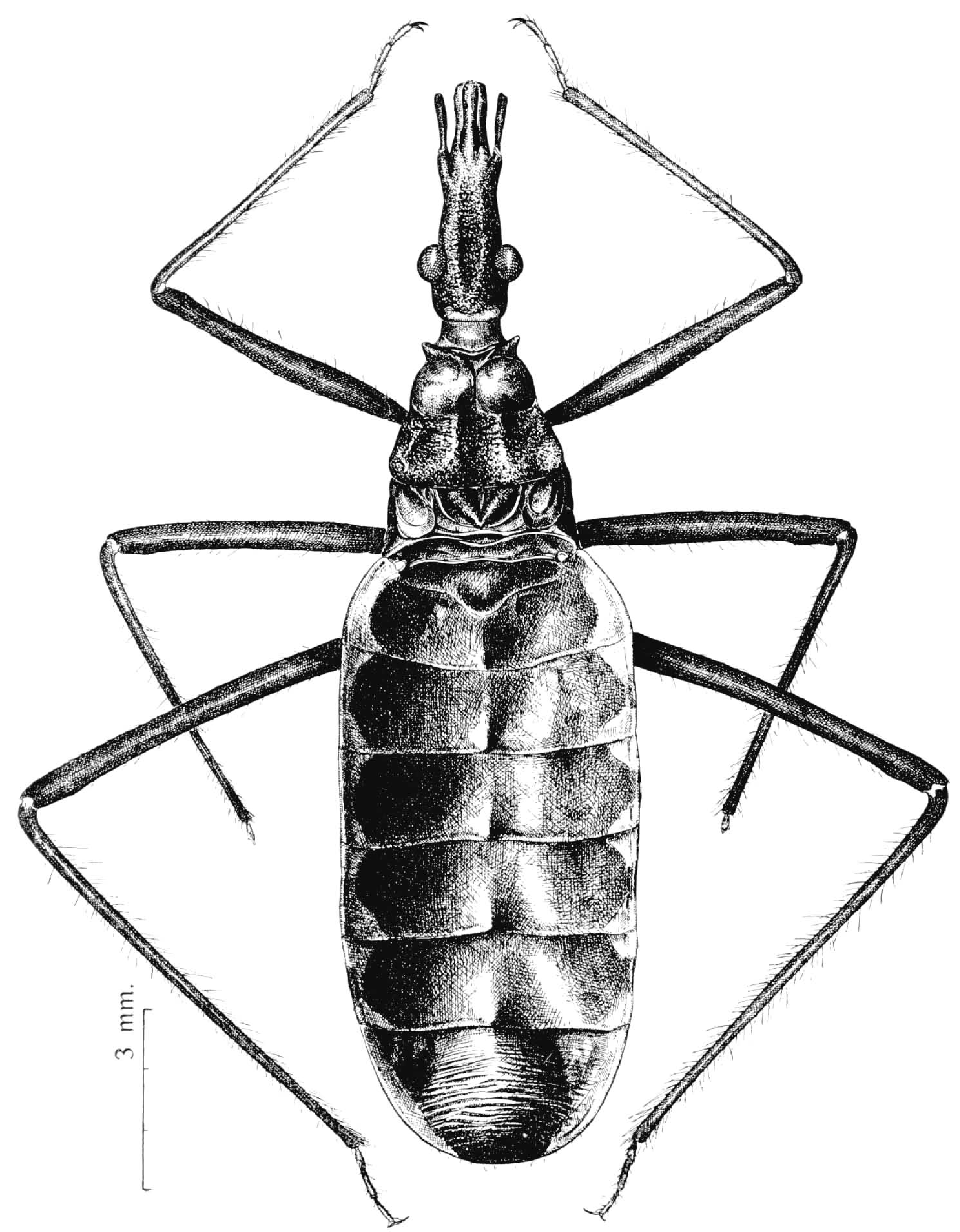

Fig. 6 - Triatomaptera pórteri Neiva \& Lent. 1940. Exemplar holótipo macho. R. Arlé del.

Cabeça de colorido castanho escuro na face superior, colorido que é mais claro sobretudo na face inferior da região post-ocular, delgada, alongada, com quase o dôbro do comprimento do pronoto, in regularmente rugosa e tuberosa, com cerdas pequenas e esparsas implantadas em pontuações e irregularmente dispostas. Região ante-ocular comprida, 
com cerca de 3,5 vezes o comprimento da região post-ocular, com tylus saliente possuindo algumas cerdas alongadas em sua parte anterior e jugae em plano mais inferior. Cerdas mais alongadas e finas são também visiveis na face inferior da cabeça ao lado do rostro quando em posição de repouso e, também, no ápice das genas. Tubérculos parafrontais visiveis, com o mesmo colorido castanho escuro. Olhos salientes lateralmente situados, cada qual com a metade da largura da distância inter-ocular (nas fêmeas a distância inter. ocular é maior, equivale a três vezes a largura de cada olho, como, também a largura da cabeça é maior do que nos machos). Ocelos salientes, brilhantes, mais próximos entre si, afastados dos olhos e implantados em saliências bem no limite posterior da região postocular, de colorido avermelhado.

Tubérculos anteníferos implantados no meio da região ante-ocular, curtos e quase sem revestimento piloso, com um grupo de cerdas fortes e curtas situadas apical e lateralmente. $10^{\circ}$ articulo antenal quase atingindo o ápice da cabeça, mais dilatado na extremidade apical, de colorido castanho escuro e raros pêlos esparsos; $2 .^{\circ}$ artículo longo, com cerca de quatro vezes o comprimento do $10^{\circ}$ e diâmetro menor, revestido de pélos muito curtos e finos e outros mais longos e delgados esparsamente dispostos. Faltam os articulos 3." e 4.".

Rostro reto, delgado, longo e achatado dorso-ventralmente, de colorido castanho es. curo, revestido de pêlos curtos e outros mais longos e finos no ápice do $3 .^{\circ}$ segmento e ao lado da cavidade onde repousa o labro no $1 .^{\circ}$ segmento. $1 .^{\circ}$ articulo do rostro forte, terminando ao nivel da implantação do $1 .^{\circ}$ artículo antenal no tubérculo antenífero quando o rostro está em posição de repouso; $2 .^{\circ}$ artículo muito longo e mais delgado, terminando ao nivel do pescoço, medindo mais de três vezes o comprimento do $1 .^{\circ}$ artículo; $3 .^{\circ}$ artículo afilado, mais delgado, com $2 / 3$ do comprimento do $1 . \circ$, repousando no sulco pro-esternal e atingindo a inserção do 1 ." par de patas.

Pescoço castanho claro sem manchas.

Tórax de colorido castanho escuro uniforme, com rarissimos pêlos esparsos e zonas rugosas, granulosas ou glabras.

Pronoto forte, bem constituido, de forma quadrangular dividido ao meio por um sulco transversal nos dois lóbulos comuns a tôdas as espécies da familia.

Lóbulo anterior grande, tão comprido ou um pouco mais comprido do que o lóbulo posterior, dividido na linha mediana por um sulco longitudinal profundo, com zonas glabras simétricas na linha mediana e lateralmente; a superfície restante do lóbulo é granulosa, ainda existindo, de cada lado da linha mediana e próximo ao sulco que limita o colarinho, um tubérculo pouco saliente de ápice obtuso. Do terço posterior do lóbulo anterior nascem as carenas longitudinais que se prolongam até a metade do lóbulo posterior e são quase paralelas. Lóbulo posterior também sem manchas, de coloração castanho escura, com a superficie enrugada e granulosa e as partes mediana e laterais escavadas. Angulos anteriores do pronoto salientes, dirigidos para diante e um pouco para fora, de ponta romba. Ângulos posteriores obtusos.

Escutelo castanho escuro, pequeno, mais largo do que comprido, implantado sôbre uma placa de contorno semi-circular, com um sulco mediano longitudinal e profundo e o ápice pouco acentuado e rombudo; de cada lado do sulco e convergindo para o ápice o escutelo é constituido por uma elevação que, com a do lado oposto, dá ao conjunto a forma de " $V$ ".

Pro- meso- e metapleuras castariho escuras. granulosas e pregueadas irregularmente. Pro-esterno quase todo ocupado pelo sulco pro-esternal que, anteriormente e de cada lado, 
possue uma grande protuberância: fora do sulco veem-se alguns pêlos finos. Meso-esterno granuloso e rugoso, provido de pêlos finos e longos, na metade posterior do qual se inicia uma crista mediana que se prolonga até o fim do meta-esterno, que também é granuloso e possue os finos pélos assinalados.

Patas uniformemente coloridas, castanho escuras, longas, revestidas de pêlos finos e longos, mais abundantes nas tíbias e nos tarsos. As patas do $1 .^{\circ}$ e $20^{\circ}$ pares são pràticamente iguais em tamanho, enquanto as do $30^{\circ}$ par são sensivelmente maiores. Fêmures sem espinhos, sómente com uma pequena saliência apical inferior. Tíbias com a metade do diâmetro dos fêmures e fosseta esponjosa bem visivel nos $10^{\circ}$ e $2 .^{\circ}$ pares. Tarsos pardacentos triarticulados, com pilosidade mais abundante do que nos demais segmentos das patas, e com duas unhas fortes.

Asas atrofiadas, pràticamente inexistentes; observa-se uma placa, coriácea em tôda a estensão, implantada de cada lado do escutelo e com o mesmo comprimento que êle, onde é visivel a sutura do clavo e uma ou outra nervura, em alguns exemplares.

Abdômen arqueado, todo descoberto na face dorsal, com sete segmentos aparentes dorsalmente (o primeiro segmento, que não é visivel nas espécies aladas, é bem nitido), preto, sòmente com um leve tom avermelhado ao nivel da porção mediana do $2 .^{\circ}$ segmento abdominal, pregueado transversalmente, com raros pêlos esparsos e uma saliência mediana em cada segmento junto à linha que os separa. O segmento genital é constituido $8 .^{\circ}, 9 .^{\circ}$ e $100^{\circ}$ segmentos abdominais. Ventralmente, o abdômen possue pilosidade maior e mais numerosa. Esstigmas salientes, arredondados, amarelados, ao nivel da metade de cada segmento e junto ao conexivo. Conexivo possue caracteristicas próprias que podem ser assim descritas, quando observado dorsalmente: machos e fêmeas $10^{\circ}$ e $2 .^{\circ}$ segmentos todo vermelho; $3 .^{\circ}, 4 .^{\circ}, 5 .^{\circ}$ e $6 .^{\circ}$ segmentos vermelho com uma faixa preta transversal e mediana; $7 .^{\circ}$ segmento todo vermelho nos machos e com a faixa preta idêntica nas fêmeas; ventralmente o aspecto é semelhante, o contôrno vermelho avançando um pouco mais sôbre o abdômen. O conexivo é constituido nas fêmeas por duas fôlhas juxtapostas, apresen. tando-se, por isso, com duas margens.

Genitália, em ambos os sexos, de colorido castanho escuro.

Proveniência - Provincia de Coquimbo, Chile. Gajardo Tobar coll., Porter leg., 1-1940.

Holótipo macho; alótipo fêmea; parátipos dois machos, uma fêmea. Todos na coleção do Instituto Osvaldo Cruz.

\section{EUTRIATOMA SORDIDA (STAL, 1859)}

Conorhinus sordidus STAL, 1859, pág. 108.

Conorhinus sordidus STAL, 1868, pág. 124.

Conorhinus sordidus STAL, 1872, pág. 111.

Conorhinus sordidus WaLkER, 1873, pág. 15.

Conorhinus sordidus BERG, 1879, págs. 166-167.

Conorhinus sordidus Leth. E Sev, 1896, pág. 117.

Conorhynus sordidus IHERING, 1911, pág. 24.

Triatoma sordida Chagas, 1912, pág. 306.

Triatoma sordida NeIVA, 1913, pág. 309.

Triatoma sordida NeIVA, 1913, pág. 197.

Triatoma sordida NeIVA, 1914, págs. 35-36, 37, 38, 39. 
Triatoma sordida NeIva 1914, pág. 334.

Triatoma sordida NeIVA, 1914, págs. 7, 10, 13, 14, 16, 17, 66.

Triatoma sordida Del Ponte, 1921, págs. 18, 23, 28, 29, 35, 56-57, fig.

Triatoma sordida Hussey, 1922, págs. 111, 112, 121.

Triatoma sordida Gaminara, 1923, pág. 11 (separado) .

Triatoma sordida Pinto, 1925, págs. 19, 25, 26, 27, 28, 29, 30, 38, 51, 99, 100 , 101, 102, 103, 105, 107.

Triatoma sordidá Pinto, 1926, págs, 27, 29, 32, fig. 5.

Triatoma sordida Gaminara, 1927, pág. 637.

Triatoma sordida PINTO, 1930, págs. 182, 188, 191, 192, 200, 206, 212, 224.

Triatoma sordida Del Ponte, 1930, págs. 901-902, 918, 919, 935, pl. 44, fig. 2.

Eutriatoma sordida PINTo, 1931, págs. 53, 100-101, figs. 43-44.

Eutriatoma sordida Neiva \& Lent, 1936, págs. 178, 181, 182, 183, 187.

Eutriatoma sordida Mazza E Jörg, 1938, págs. 26-38, quadro, figs. 1-7, lám. 1. Eutriatoma sordida Lent, 1939, págs. 593, 595.

\section{Descrição original}

4. C. sordidus Stal : Sordide griseo-flavescens, antennarum articulis primo et secundo, thorace (macula utrimque posteriore excepta), venis corii apicem versus, pectore, serie utrimque ventris macularum annuloque apicali femorum fusco-testaceis; maculis connexivi nigris. of Long. 20, Lat. 4- I/2 Millim.

Patria : Brasilia.

Sordide griseo-flavescens. Caput thorace paullulum longius, lobis lateralibus medio sublongioribus, obtusis. Oculi modice prominentes. Rostrum crassiusculum, articulo apicali piloso, basali nonnihil longiore. Antennae articulis duobus basalibus fuscis, articulo basali capitis apicem vix attingente, secundo illo plus ter longiore. Thorax fusco-testaceus, lobo antico rugis flavescentibus; lobo postico ruguloso, posterius utrimque macula griseo-flavescente ornato. Scutellum fusco-testaceum, apice paullulum productum, ibidem pallidum. Hemelytra abdomine subbreviora, macula minuta prope basin marginis costalis nec non venis corii apicem versus ad membranam fuscis. Pectus fusco-testaceum, rugosum, anteriur dense, posterius remotius ruguloso- granulatum. Abdomen disco planiusculo, maculis connexivi marginalibus parvis nigricantibus, serie macularum utrimque laterali ventris fusca. Femora apice fusca, anteriora subtus prope apicem spinulis duabus armata. Tibiae apicem versus fuscae, anteriores (foeminarum saltem) absque fossula spongiosa.

\section{Redescrição}

(Vide estampa 4)

Comprimento : of $18-19 \mathrm{~mm}$; o $19.20 \mathrm{~mm}$.

Largura - (ao nível do pronoto) ô 4,5-5 mm; (ao nível do abdômen) ô 6,5-7 $\mathrm{mm}$; ㅇ $7-8 \mathrm{~mm}$.

Inseto pequeno, de colorido geral pardacento com manchas amareladas no pronoto, élitros, patas e conexivo, revestido de fraca pubescência.

Cabeça pardacenta, com tonalidades amareladas em certas regiões principalmente na ante ocular, curta, levemente mais longa do que o pronoto, rugosa e revestida de pontuações 
onde se implantam pequenas cerdas amarelas dirigidas para diante; tylus bem visivel, amarelado; jugae ultrapassando o apice do tylus, amareladas também. Tubérculos parafrontais nítidos, amarelados e duas manchas do mesmo colorido logo abaixo dêles. Destas manchas para trás, isto é, nas regiōes post-ocular e inter-ocular, o colorido é uniformemente pardacento. Região ante-ocular cerca de três vezes maior que a post-ocular. Olhos salientes, largos, com o diâmetro igual ao da distância inter-ocular, aproximados inferiormente. Ocelos afastados dos olhos, para trás, grandes e brilhantes, mais próximos entre si, implantados em saliências divergentes. Tubérculos anteniferos implantados no meio da região ante-ocular, com algumas cerdas mais fortes situadas no ápice e lateralmente, articulando-se por um segmento amarelo com o primeiro artículo antenal que é pardacento, revestido de poucas cerdas curtas e não atinge o ápice da cabeça; a articulação entre o primeiro e segundo articulos também é amarela; êste é uniformemente pardacento, possue cerdas pretas abundantes em toda sua extensão, é longo com cerca de quatro vezes o comprimento do primeiro; terceiro articulo amarelo claro, mais delgado, com cerdas finas e curtas e outras longas e aciculares menos abundantes com $2 / 3$ do comprimento do segundo; quarto artículo com aspecto idêntico ao do terceiro, porém menor que êle.

Rostro reto, pardacento, revestido de cerdas curtas e outras maiores no ápice, achatado dorso-ventralmente; primeiro artículo forte, curto, não atingindo o nivel da implantação do primeiro artículo antenal; segundo articulo com mais do dôbro do comprimento do primeiro, atingindo o nivel do bordo posterior dos olhos; terceiro artículo afilado, longo, do mesmo comprimento do primeiro ou levemente maior.

Pescoço pardacento, com manchas amarelas de cada lado e inferiormente.

Tórax de colorido pardo, com manchas amarelas no pronoto e ápice do escutelo, revestido de curtas cerdas.

Pronoto de forma trapezoidal, revestido de curtas cerdas irregularmente distribuidas. O lóbulo anterior tem cerca de $1 / 3$ do comprimento total do pronoto e possúe zonas glabras de colorido pardacento, por entre as quais se insinuam manchas amarelo-alaranjadas sôbre pequenas elevações do tegumento, granulosas e irregularmente pontuadas, onde se implantam cerdas pretas curtas; neste lóbulo, anteriormente, de cada lado da linha mediana, existe uma saliência pequena de colorido amarelado, abaixo das quais nascem as carenas longitudinais que se prolongam até quase o bordo posterior do lóbulo posterior. O colarinho é profundamente separado do lóbulo anterior, pardacento, porém os ângulos anteriores são amarelos e se dirigem para fora e para diante. O lóbulo posterior é rugoso e pontuadó, mostrando cerdas curtas amareladas e mancha amarela pequena para dentro dos ângulos posteriores e ao nivel dêles. Ângulos posteriores pouco pronunciados.

Escutelo triangular, rugoso, com cerdas curtas esparsas, de colorido pardacento, com uma escavação cordiforme mediana, delimitada por duas cristas laterais e duas saliências anteriormente; o ápice é reto, levemente levantado, rugoso na base e liso na ponta que é amarela.

Proesterno pardo, granuloso e com cerdas esparsas e sulco proesternal delimitado lateralmente por calosidades. Meso- e meta-esterno lisos, pardos, com cerdas curtas raras; aquele com uma saliência transversal em forma de barra e êste com uma crista longitudinal mediana pronunciada que faz ligação com o meso-esterno. Pleuras rugosas, granulosas e pontuadas com cerdas mais abundantes, porém ainda pouco numerosas, pardacentas e sem detalhes importantes.

Patas curtas, a posterior maior; coxas e trocânteres amarelos com manchas pardacentas irregulares. Fêmures amarelos, com um par de espinhos na região apical e inferior dos 
dois primeiros pares e uma elevação no terceiro par, revestidos de cerdas curtas de colorido preto, com um anel pardacento situado do par de espinhos para o ápice, mas sem atingi-lo e outra mancha pardacenta mais clara não delimitada sôbre todo o dorso do fêmur, mancha mais nitida no terceiro par. Tíbias pardacentas, revestidas de cerdas curtas e pretas em tôda a estensão e com fosseta esponjosa muito nitida nos dois primeiros pares. Tarsos triarticulados e duas unhas fortes.

Hemi-élitros cobrindo todo o abdômen, de tonalidade geral pardacenta, porém com èste colorido mais acentuado sôbre as nervuras e no ápice do cório. Nervulação como na figura.

Abdomen pardacento inferiormente todo revestido de cerdas curtas, podendo, entretanto, ser manchado de amarelo, colorido que é mais constante sôbre os bordos externos onde estão, em cada segmento, os orifícios estigmáticos que são pequenos, arredondados e situados no meio de cada segmento junto ao conexivo.

Conexivo largo, levemente arqueado, amarelo, com manchas pretas em forma de nota de música, isto é, uma faixa preta estreita sôbre a intersecção dos segmentos, faixa que se dilata em mancha arredondada nos bordos do conexivo.

Genitália desenvolvida em ambos os sexos e pilosa.

\section{Distribuï̧ão geográfica}

E' espécie de distribuïção ampla, pois tem sido referida na Argentina, no Brasil, na Bolivia e agora, pela primeira vez, no Chile, de onde, entretanto, não sabemos a localidade.

No Uruguai foi assinalada por NeIva, em 1914 e Gaminara, em 1923 e em 1927, o qual posteriormente, segundo informa Del Ponte (1930), a eliminou da lista que publicára.

\section{Hábitos}

E' espécie doméstica, existindo no Brasil, principalmente em zonas onde se encontram cursos dágua. Tem sido encontrada também, em galinheiros, currais, sob montes de madeiras e em ninhos de pássaros.

\section{Infestação}

Existe naturalmente infestada pelo $S$. cruzi no Brasil, onde foi pela primeira vez observada nestas condições, em 1914, por CARINI \& MăCIEL; na Argentina, em 1938, também foi assim referida por Mazza.

Queremos expressar os nossos agracecimentos ao Prof. Carlos E. Porter que tudo nos facilitou para que realizássemos o presente trabalho, feito por solicitação sua e que 
procuramos realizar não nos poupando esforços, também em homenagem a quem há tantos anos, de modo tão devotado, se tem batido pelo desenvolvimento da Ciência na América do Sul.

Estamos, também, reconhecidos ao $\mathrm{Dr}$. ROBERT L. Usinger que tão gentilmente nos remeteu o cotipo de $T$. chilena.

\section{B I B L I O G R A F I A}

BERG, C.

1879. Hemiptera Argentina. Enumeravit speciesque novas. VIII + 316 págs., Buenos Aires, Hamburgo.

Blanchard, E. E Brullé, A.

1837/1843. Insectes de l'Amérique Méridionale. In "Voyage dans l'Amerique Méridionale" par Alcide d'Orbigny, t. 6, 2ème partie, 222 págs., 32 pls. col. - Paris.

BRUMPT, E.

1910. Précis de Parasitologie, 1. ${ }^{\mathrm{a}}$ ed. - Paris.

Champion, G. C.

1899. Biologia Centrali-Americana Hemipt.-Heteropt., 2, XVI + 416 págs, 22 pls.London.

Darwin, C.

1839. Narrative of the Surveying Voyages of His Majesty's Ships Adventure and Beagle, between the years 1826 and 1836, Describing Their Examination of the Southern Shores of South America, and the Beagle's Circumnavigation of the Globe, v. 3, págs. 403-404 - London.

Del Ponte, E.

1921. Contribución al estudio del gen. Triatoma Lap. (Segunda parte). Rev. Inst. Bact. Dep. Nac. Hig., B. Aires, 3 (1) : 133-196, láms. 10-15.

Del Ponte, E.

1930. Catálogo descriptivo de los gêneros Triatoma Lap., Rhodnius Stal y Eratyrus Stal. Rev. Inst. Bact. Dep. Nac. Hig., B. Aites, 5 (8) : 855-937, 25 figs., 13 pls.

DOBRIZHOFFER, M.

1784. An Account of the Abipones, 2:329.

Dussert, E., Faiguenbaum, J. E Neghme. A.

1940. La reaccion de Machado en Chile. Rev. Chil. Hig. y Med. Prev., 2 (7/12): 197-203.

Gajardo Tobar, R.

1939. El Schizotrypanum cruzi y sus agentes vectores en Chile. Rev. Chil. Hist. Nat., 42 : 132-137, lám. 9 (1938). 
Gajardo Tobar, R.

1939. Enfermedad de Chagas. Prensa Med. y Med. Social, 3 (19) : 35-36, 13 figs. - Valparaiso.

Gajardo Tobar, R.

1939. Enfermedad de Chagas en Chile. Med. Mod., 12 (7) : 413.

Gaminara, A.

1923. Estudio experimental sobre Schizotripanum cruzi y enfermedad de Chagas en el Uruguay. Anal. Fac. Med., 8 : 49 pág., 9 láms. (separado).

Gaminara, A.

1927. Notas sobre triatomas uruguayas, 3." Reun. Soc. Argent. Patol, Reg. del Norte, págs. 636-642, figs. 1-5.

Gasic, L. G.

1938. Indice de la infestacion por el Schizotripanum cruzi de las vinchucas en algunas localidades de la provincia de Santiago. Rev. Chil. Hig. y Med. Prev., $1(7 / 9)$ : 403-405.

GASIC, G.

1939. Indice de infestacion por Trypanosoma cruzi de los triatomides de la Provin. cia de Coquimbo, Rev. Chil. Hig. y Med. Prev., 2 (1/3) : 17-20.

Gasic, G.

1939. Enfermedad de Chagas. Rev. Chil. Hig. y Med. Prev. 2 (4/6) : 107-168, figs. 1-23.

GASIC, G.

1939. Primer caso agudo de enfermedad de Chagas en Chile. Rev. Med. de Chile, 67 (1):

Gasic, G.

1939. Primer caso agudo de enfermedad de Chagas en Chile. Rev. Soc. Pediatria Chile, 10 (1).

Gasic L., G.

1939. Indice de infestación por Tripanosoma cruzi de los triatomideos del Dpto. de Elqui. Prensa Med. y Med. Social, 3 (19) : 37-38.

GASIC, G.

1940. Indice de infestacion por Tripanosoma cruzi de los triatomideos del Departamento de Elqui. Rev. Chil. Hig. y Med. Prev., 2 (7/12) : 205-210 (1939).

Gasic, G.

1940. Primer caso de Enfermedad de Chagas confirmado en Domeyko mediante el xenodiagnostico. Rev. Chil. Hig. y Med. Prev., 2 (7/12): 211-214, 1 fig. (1939) . 
Gasic, G. E Bertin, V.

1940. Animales reservatorios de virus de la tripanosomosis americana en Chile. Rev. Chil. Hig. y Med. Prev., 2 (7/12) : 247-261, figs. 1-7 (1939).

Gasic, G. E Chait, P.

1940. Once nuevos casos de Enfermedad de Chagas en Chile. Rev. Chil. Hig. y Med. Prev., 2 (7-12) : 215-245, figs. (1939).

Gasic, G., Soza. M. E Faiguenbaum, J.

1939. Dos nuevos casos de enfermedad de Chagas en Chile. Prensa Med. y Med. Social, 3 (19) : 38-39.

Gasic, G., Soza, M. \& Faiguenbaum, J.

1940. Dos nuevos casos de Enfermedad de Chagas en Chile. Rev. Med. Chile, 68 (1) : 30-35, 1 fig.

Herrich-Schaeffer, G. A. W.

1848. Die Wanzen-artigen Insecten, vol. 8.

HUSSEY, R. F.

1922. A bibliographical notice on the reduviid genus Triatoma (Hemip.). Psyche, 29 (3) : 109-123.

IHERING, R. v.

1911. Percevejos brazileiros hematophagos ou sugadores de sangue. Chacaras $e$ Quintaes, 3 (2) : 23-25, figs. 1-7.

KLug. F.

1834. In Reise um die Erde. In den Jahren 1830, 1831, und 1832, ausgefuert von $F$. J. F. Meyen - Berlin. Teil 1, pág. 412.

LARROUSSE, F.

1924. Triatomes d'Asie; description d'une nouvelle espèce Triatoma Bouvieri n. sp., Ann. Parasit., 2 (1) : 62-70, figs. 1-4.

LENT, H.

1939. Sobre o hematofagismo da Clerada apicicornis e outros artropodos; sua im. portancia na transmissão da doença de Chagas. Mem. Inst. Oswaldo Cruz, 34 (4) : 583-606, figs. $1-4$

LENZ, R.

1910. Diccionario Etimologico de las Voces Chilenas Derivadas de Lenguas Indigenas Americanas., pág. 767 (1551) - Santiago.

Lethierry, L. E Severin, G.

1896. Catalogue général des Hémiptères, vol. 3, 275 págs. - Berlin. 
Massa S., M.

1931. El Trypanosoma cruzi en los alrededores de Melipilla. Rev. Inst. Bact. Chile, 2 (2) : 87-89, 1 fig.

MAYr, G. L.

1868. Hemiptera. In Reise der Osterreichischen Freggate Novara. Zool., Teil 2, Abt, 1, 204 págs., 5 pls. - Wien.

Mazza. S., Gajardo Tobar, R. E Jörg, M. E.

1940. Investigaciones sobre Triatomidae. Mepraia novum genus de Triatomidae. Mepraia spinolai (Porter) 1933, nov. comb., redescripción de macho y des. cripción de hembra. Mis. Est. Pat. Reg. Atgentina, Jujuy, Publ. 44, 30, págs. 27 figs.

Mazza, S. E JÖRG, M.

1938. Tercera nota sobre Triatomidae (Hemipt. Het. Reduvioidea) argentinos. Mis. Est. Pat. Reg. Argentina, Jujuy, Publ. 36 (II) : 26-58, figs. 1-21, láms. 1-6.

Neghme R., A.

1939. La trypanosomosis americana una enfermedad rural en Chile. Prensa Med. y Med. Social, 3 (19) : 36-37.

NeIVA, A.

1911. Contribuição ao estudo dos hematophagos brasileiros e descrição de uma nova especie de Triatoma. Brasil-Med., 25 : 461-462.

NeIva, A.

1913. Informações sobre a biologia da vinchuca, Triatoma infestans Klug, Mem. Inst. Oswaldo Cruz, 5 : 74-77.

NeIva, A.

1913. Da transmissão do Trypanosoma cruzi pela Triatoma sordida Stal. BrasilMed., 27 : 309.

NeIVA, A.

1913. Multiplicação na vinchuca (Triatoma infestans Klug) do trypanosoma do mal de cadeiras (Nota prévia). Brasil-Med., 27 : 366-367.

Neiva, A.

1913. Algunos datos sobre Hemipteros hematófagos de la America del Sur, con la descripción de una nueva especie. Anal. Mus. Nac. Hist. Nat., B. Aires, 24 : 195-198.

Neiva, A.

1914. Contribuição para o estudo dos redúvidas hematophagos. Notas sobre os redúvidas hematophagos da Bahia, com a descripção de nova especie. Mem. Inst. Oswaldo Cruz, 6 : 35-39. 
Neiva, A.

1914. Revisão do genero Triatoma Lap. These para a livre docencia Fac. Medicina Rio de Janeiro. 80 págs. - Rio de Janeiro.

Neiva, A.

1914. Presença em uma localidade do Estado do Rio de um novo transmissor da moléstia de Chagas, encontrado infectado em condições naturaes (Nota prévia). Brasil-Med., 28 : 333-335.

Neiva, A. E Lent, H.

1936. Notas e commentarios sobre triatomídeos. Lista de especies e sua distribuição geographica. Rev. Ent., 6 : 153-190.

Neiva, A. E Lent, H.

1940. Sobre um novo triatomídeo chileno: Triatomaptera porteri (Nota prévia). Brasil-Med., 54 (15) : 265-267.

Neiva, A. E Lent, H.

1940. Estudos sobre triatomideos do Chile: Interessante caso de provavel polimorfismo. Mem. Inst. Oswaldo Cruz, 35 (2) : 343-363, figs. 1-6.

Pessôa, S. B. E Barros, N. V.

1939. Criação do Triatoma infestans na temperatura de estufa. Folha Méd., 20 (18) : 285-287.

PoEppig, E.

1835. Reise in Chile, Peru und Auf dem Amazonenstrome während der Jahre 1827. 1832. Erster Band, págs. 255-256 - Leipzig.

Philippi, A. R.

1860. Viage al Desierto de Atacama (Reise durch die Wueste Atacama) hecho del orden del Gobierno de Chile en el verano 1853-54. VIII + 236 págs., tabs. Halle.

Pinto, C.

1925. Ensaio monographico dos reduvideos hematophagos ou "barbeiros". These Fac. Med. Rio de Janeiro, 118, págs. 58 figs. - Rio de Janeiro.

Pinto, C.

1926. Hypopygio dos Triatomideos (Hemipteros-Heteropteros Hematophagos) e do genero Apiomerus. Bol. Biol., 2 : 27-33, figs. 1 7.

PinTo, C.

1927. Classification de genres d'Hémiptères de la famille Triatomidae (Reduvidioidea). Bol. Biol., 8 : 103-114, figs. 1-13.

Pinto, C.

1930. Arthropodes parasitos e transmissores de doenças. Vol. 1. - Rio de Janeiro, 
Pinto, C.

1931. Valor do rostro e antenas na caracterisação dos generos de Triatomídeos (Hemiptera, Reduvidioidea). Bol. Biol.. $19: 45-136,70$ figs., 1 quadro.

Porter, C. E.

1920. Datos para la Zoologia Médica de Chile. Anal. Zool. Aplic., 7 (1/2): 16-19, fig. 2.

Porter, C. E.

1934. Una Triatoma nueva chilena. Rev. Chil. Hist. Nat., 37 : 192-193 (1933).

Porter, C. E.

1939. Notas de Parasitologia. Rev. Chil. Hist. Nat., 42 : 122-124, lám. 8 (1938).

Porter, C. E.

1939. Algunos insectos de las provincias de Atacama y Coquimbo. Rev. Chil. Hist. Nat., 42 : 154 155 (1938).

RaILliet, A.

1895. Traité de Zoologie Médicale et Agricole. 2e. éd.

REED, E. C.

1898-1901. Entomologia Chilena. Sinopsis de los Hemipteros de Chile. Rev. Chil. Hist. Nat. años 2, 3, 4 e 5, 107 págs., 1, lám. (separado).

SIGNORET, V.

1863. Révision des Hémiptères du Chili. Ann. Soc. Ent. France, 4e. sér., t. $3: 541$. 588, pls. 11-13.

SPinola, M.

1852. In Historia Fisica y Politica de Chile por Claudio Gay, $7: 113-238$ (cf. pá gina 218).

IITAL, C.

1859. Monographie der Gattung Conorhinus und Verwandten. Berl. Ent. Zeits., 3 : 99-117, tab. 6, figs. 1-4.

Stal, C.

1868. Hemiptera Fabriciana. Svensk. Vet.-Ak. Handl., 8 (2) : 1-148.

STÁt, C.

1872. Enımeratio Hemipterorum. Svensk. Vet.-Ak. Handl., 10 (4) : 1-159.

Tal.icz, R.-V., Costa, R.-S., Rial, B. E Osimani, J.-J.

1940. Los 100 primeiros casos agudos confirmados de Enfermedad de Chagas (Tripanosomiasis americana) en el Uruguay. 349 págs., 162 figs., 2 láms. col. 
USINGER, R.-L.

1939. Descriptions of new Triatominae with a key to genera (Hemiptera, Reduviidae). Univ. Calif. Publ. Ent., 7 (3) : 33-56, 1 pl.

WALKER, F.

1873. Catalogue of the specimens of Hemiptera Heteroptera in the collection of the British Museum. Part. 8, 220 pág. - Londres. 


\section{ESTAMPA 1}

Triatoma infestans (Klug in Meyen, 1834). Exemplar fêmea. A. Pugas del. 
MEM. INST. OSWALDO CRUZ

EST. 1

39 (1), AGOSTO, 1943

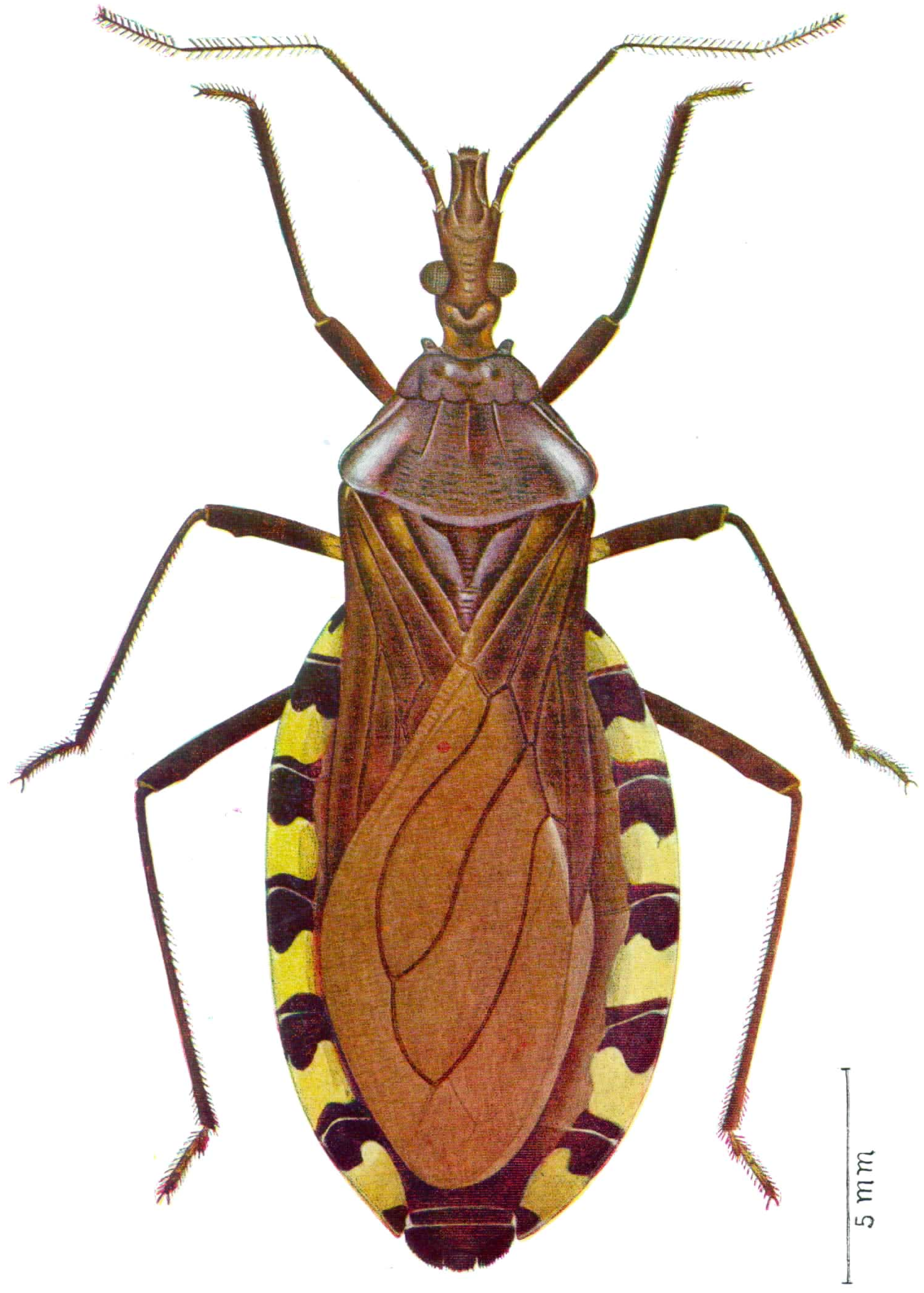

Neiva E Lent: Triatomídeos do Chile 


\section{ESTAMPA 2}

Eutriatoma rubrovaria (Blanchard in Blanchard E Brullé, 1843) Exemplar fêmea.

A. Pugas del. 


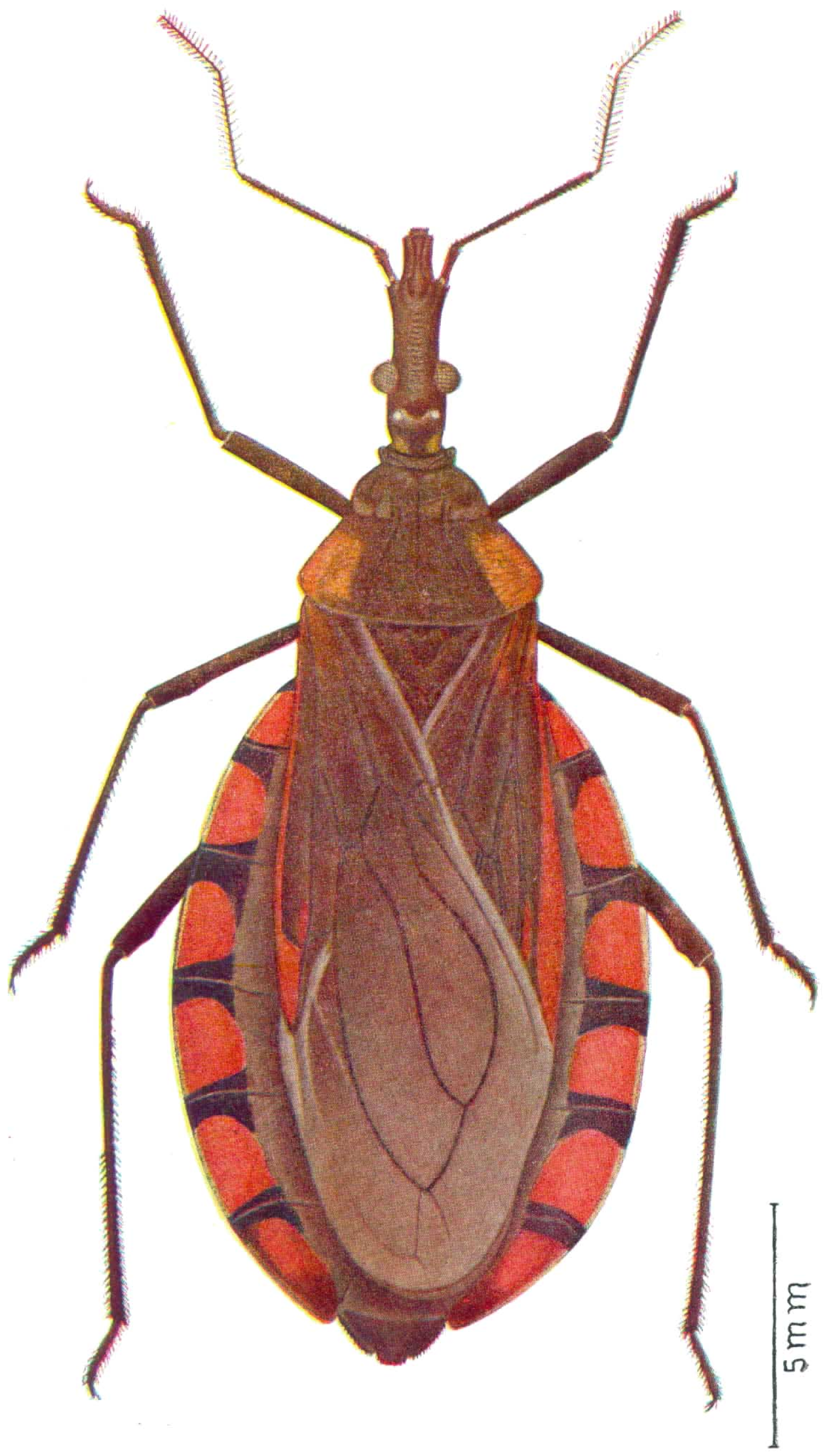

Neiva \& Lent: Triatomideos do Chile 
ESTAMPA 3

Triatomaptera porteri Neiva $\mathcal{E}$ Lent, 1940. Exemplar macho. A. Pugas del. 


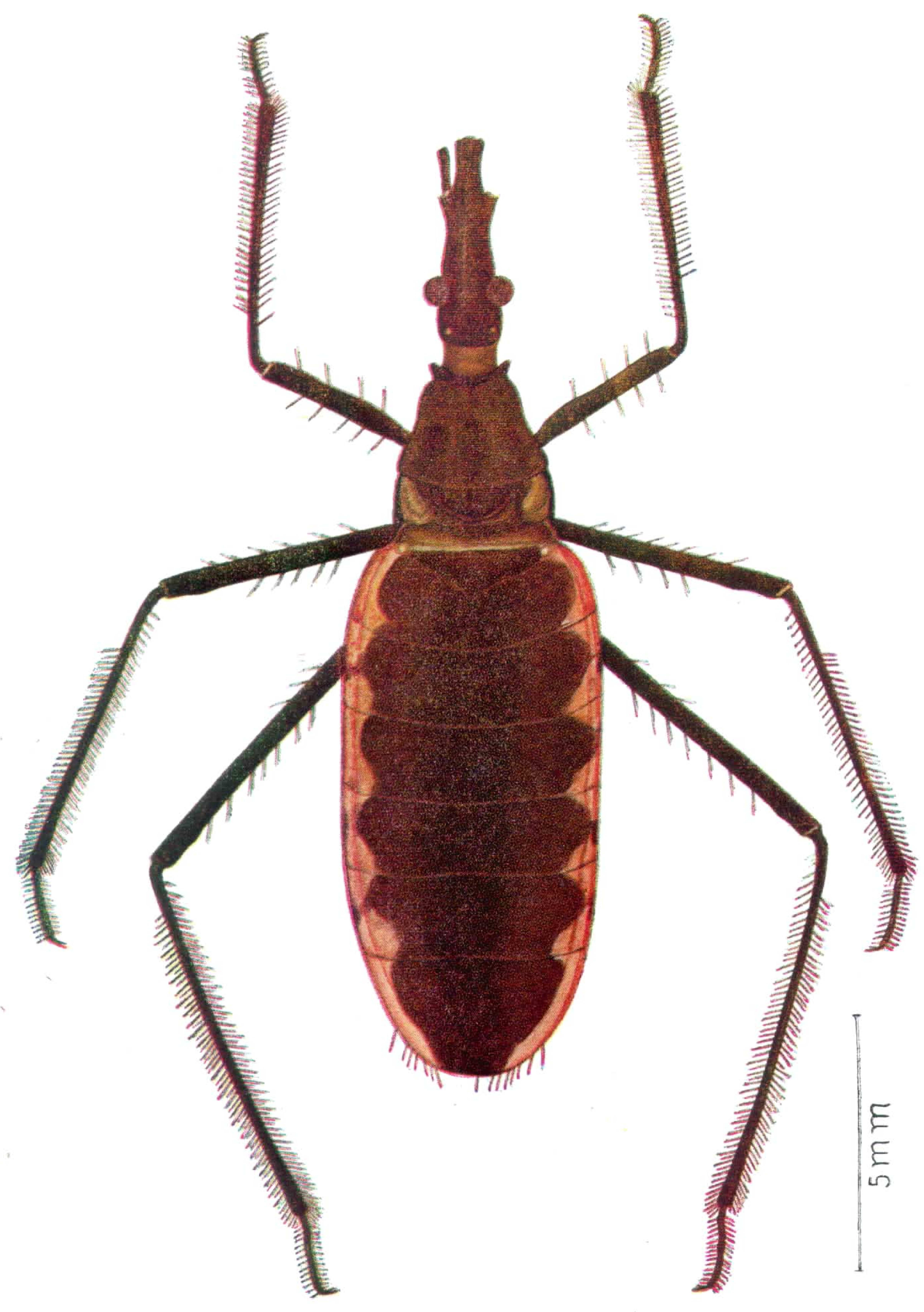

Neiva E Lent: Triatomídeos do Chile 


\section{ESTAMPA 4}

Eutriatoma sordida (Stal, 1859). Exemplar macho. A Pugas del. 
MEM. INST. OSWALDO CRUZ

EST. 4

39 (1), AGOSTO, 1943

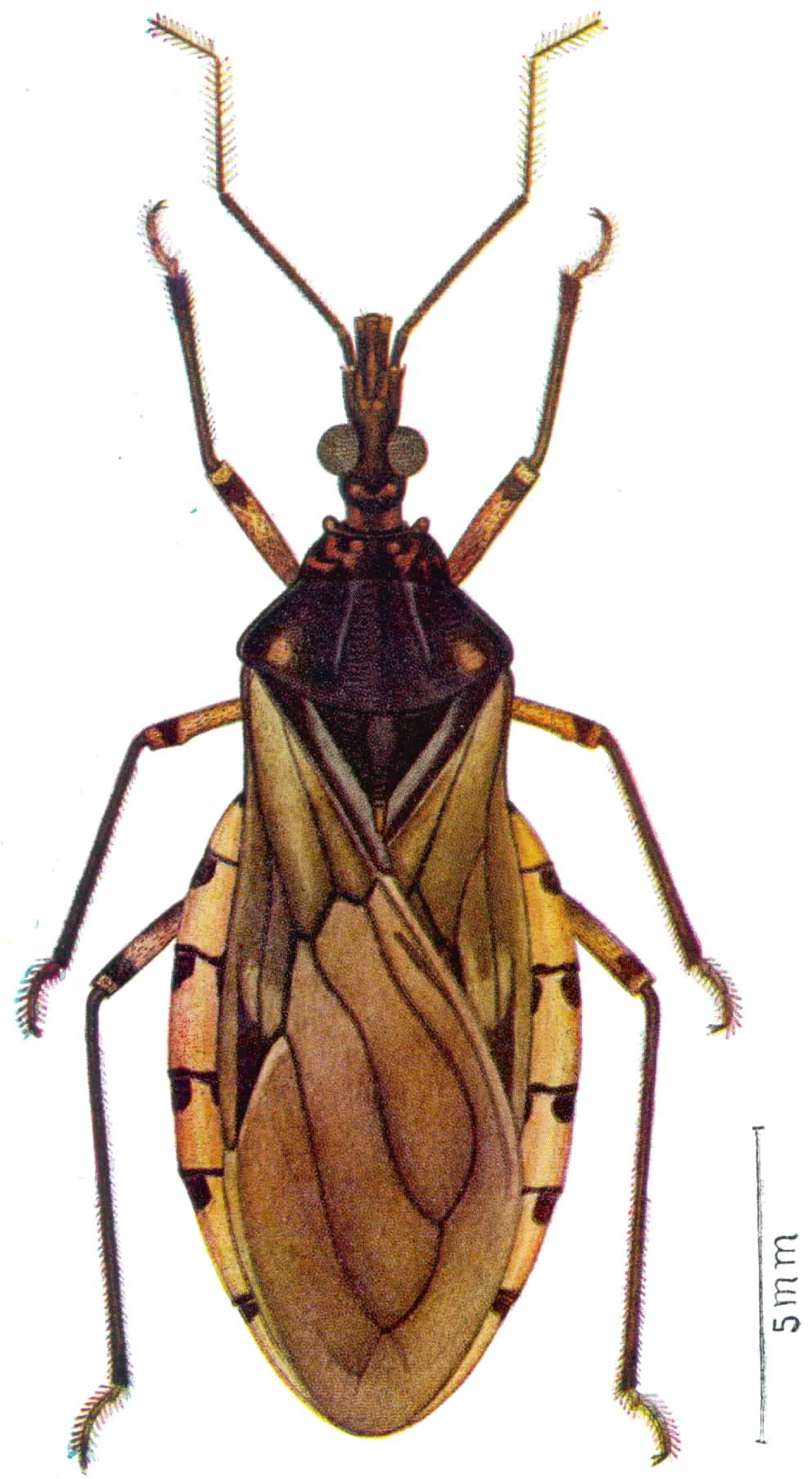

Neiva \& Lent: Triatomídeos do Chile 